\title{
Effects of fertilizations on soil bacteria and fungi communities in a degraded arid steppe revealed by high through-put sequencing
}

\author{
Luhua Yao ${ }^{1}$, Dangjun Wang ${ }^{1}$, Lin Kang ${ }^{1}$, Dengke Wang ${ }^{1}$, Yong Zhang ${ }^{2}$, Xiangyang Hou ${ }^{2}$, Yanjun Guo \\ Corresp. 1 \\ ${ }^{1}$ College of Agronomy and Biotechnology, Southwest University, Chongqing, China \\ 2 Institute of Grassland Research, Chinese Academy of Agricultural Sciences, Hohhot, China \\ Corresponding Author: Yanjun Guo \\ Email address: qhgyj@swu.edu.cn
}

Background. Fertilization as one of the measures in restoring degraded soil qualities has been introduced on arid steppes in recent decades. However, the fertilization use efficiency on arid steppes varies greatly between steppe types and years, enhancing uncertainties and risks in introducing fertilizations on such natural system to restore degraded steppes. Methods. The experiment was a completely randomized design with five fertilization treatments, 0 (Control), $60 \mathrm{~kg} \mathrm{P} \mathrm{ha}^{-1}(\mathrm{P}), 100 \mathrm{~kg} \mathrm{~N} \mathrm{ha}^{-1}(\mathrm{~N}), 100 \mathrm{~kg} \mathrm{~N} \mathrm{ha}^{-1}$ plus $60 \mathrm{~kg} \mathrm{P} \mathrm{ha}^{-1}(\mathrm{NP})$, and $4000 \mathrm{~kg}$ sheep manure ha-1 $\left(\mathrm{M}\right.$, equaling $16.4 \mathrm{~kg} \mathrm{P} \mathrm{ha}^{-1}$ and 81.2 $\mathrm{kg} \mathrm{N} \mathrm{ha}{ }^{-1}$ ). Soils were sampled from a degraded arid steppe which was consecutively applied with organic and inorganic fertilizers for three years. We analyzed the diversity and abundance of soil bacteria and fungi using high-throughput sequencing technique, measured the aboveground biomass, the soil chemical properties (organic carbon, available and total phosphorus, available and total nitrogen, and $\mathrm{pH}$ ), and the microbial biomass nitrogen and microbial biomass carbon. Results. In total 3927 OTU Coperational taxonomic units $)$ for bacteria and 453 OTU for fungi were identified from the tested soils. The Ace and Chao of bacteria were all larger than 2400, which were almost 10 times of those of fungi. Fertilizations had no significant influence on the richness and diversity of the bacteria and fungi. However, the abundance of individual bacterial or fungi phylum or species was sensitive to fertilizations. Fertilization, particularly the phosphorus fertilizer, influenced more on the abundance of the AMF species and colonization. Among the soil properties, soil pH was one of the most important soil properties influencing the abundance of soil bacteria and fungi. Discussion. Positive relationships between the abundance of bacteria and fungi and the soil chemical properties suggested that soil bacteria and fungi communities in degraded steppes could be altered by improving the soil chemical properties through fertilizations. However, it is still not clear whether the 
alteration of the soil microbe community is detrimental or beneficial to the degraded arid steppes. 
1 Effects of fertilizations on soil bacteria and fungi communities in a degraded

2

3

4

5

6

7

9

10

11

12

13

5 8 China

\section{arid steppe revealed by high through-put sequencing 1}

Luhua Yao ${ }^{1}$, Dangjun Wang ${ }^{1}$, Lin Kang ${ }^{1}$, Dengke Wang ${ }^{1}$, Yong Zhang ${ }^{2}$, Xiangyang Hou ${ }^{2}$, Yanjun Guo ${ }^{1 *}$

${ }^{1}$ College of Agronomy and Biotechnology, Southwest University, Chongqing 400716, China;

${ }^{2}$ Institute of Grassland Research, Chinese Academy of Agricultural Sciences, Hohhot 010010,

*Correspondence author: Yanjun Guo; Tel: +86 23 68251264; E-mail: qhgyj@126.com 


\section{Abstract}

15

Background. Fertilization as one of the measures in restoring degraded soil qualities has been introduced on arid steppes in recent decades. However, the fertilization use efficiency on arid steppes varies greatly between steppe types and years, enhancing uncertainties and risks in introducing fertilizations on such natural system to restore degraded steppes.

Methods. The experiment was a completely randomized design with five fertilization treatments, 0 (Control), $60 \mathrm{~kg} \mathrm{P} \mathrm{ha}^{-1}(\mathrm{P}), 100 \mathrm{~kg} \mathrm{~N} \mathrm{ha}^{-1}(\mathrm{~N}), 100 \mathrm{~kg} \mathrm{~N} \mathrm{ha}^{-1}$ plus $60 \mathrm{~kg} \mathrm{P} \mathrm{ha}^{-1}$ (NP), and 4000 $\mathrm{kg}$ sheep manure ha-1 $\left(\mathrm{M}\right.$, equaling $16.4 \mathrm{~kg} \mathrm{P} \mathrm{ha}^{-1}$ and $\left.81.2 \mathrm{~kg} \mathrm{~N} \mathrm{ha}^{-1}\right)$. Soils were sampled from a degraded arid steppe which was consecutively applied with organic and inorganic fertilizers for three years. We analyzed the diversity and abundance of soil bacteria and fungi using high-throughput sequencing technique, measured the aboveground biomass, the soil chemical properties (organic carbon, available and total phosphorus, available and total nitrogen, and $\mathrm{pH}$ ), and the microbial biomass nitrogen and microbial biomass carbon.

Results. In total 3927 OTU (operational taxonomic units) for bacteria and 453 OTU for fungi were identified from the tested soils. The Ace and Chao of bacteria were all larger than 2400, which were almost 10 times of those of fungi. Fertilizations had no significant influence on the richness and diversity of the bacteria and fungi. However, the abundance of individual bacterial or fungi phylum or species was sensitive to fertilizations. Fertilization, particularly the phosphorus fertilizer, influenced more on the abundance of the AMF species and colonization. Among the soil properties, soil $\mathrm{pH}$ was one of the most important soil properties influencing the abundance of soil bacteria and fungi.

Discussion. Positive relationships between the abundance of bacteria and fungi and the soil 
35 chemical properties suggested that soil bacteria and fungi communities in degraded steppes could

36 be altered by improving the soil chemical properties through fertilizations. However, it is still not

37 clear whether the alteration of the soil microbe community is detrimental or beneficial to the 38 degraded arid steppes. 


\section{INTRODUCTION}

40 Steppe is the largest land ecosystem in China, which plays important roles in providing life necessities,

41 ecological services and recreations for human beings (Du et al. 2014; Ren et al. 2016). However, long-

42 term drought, frequent human activities and overgrazing have caused severe steppe degradation such as decreases of soil qualities and productivities (Zhao et al. 2009; Bai et al. 2012). Fertilization as one of the measures in restoring degraded soil qualities has been introduced on steppes in recent decades, mainly concentrating on its efficiency in improving soil nutrient conditions (Gong et al. 2011), increasing aboveground biomass and vegetation coverage (Zhou et al. 2016; Yang et al. 2011), and enriching ecological biodiversity (Symstad and Jonas 2011). However, the fertilization use efficiencies in steppes varied greatly between steppe types and years ( $\mathrm{Su}$ et al. 2014; Zhou et al. 2016; Yang et al. 2011). This increased the uncertainties in restoring the degraded steppes through fertilization and the risk in introducing more fertilization into such natural system. microbial communities play critical roles in ecosystem function and regulate key processes such as carbon and nitrogen cycles (Balser and Firestone 2005; Bragazza et al. 2015). In a Tibetan alpine meadow, nitrogen $(\mathrm{N})$ and phosphorus $(\mathrm{P})$ additions reduced the biomass of the whole microbial community, gram negative bacteria and fungi (Guo et al. 2017). In a subtropical forest in East China, soil microbial biomass was enhanced by mixed $\mathrm{N}$ fertilization (Guo et al. 2011). The different responses of the soil microbes to fertilizations, on one hand, are attributed to the differences in the contents of soil total carbon (C), N and P (Yu et al. 2013), and the differences of soil water conditions and plant species (Huang et al. 2018). On the other hand, the soil microbe communities in different ecosystems are different, and thus their 
60

61

62

63

64

responses to similar fertilizations might also be different.

1 During the long-term evolution process, the soil, plants and microbes have co-evolved, forming relatively stable relationships under certain ecosystem (terHorst et al. 2014). In this relationship, genetic variation in plant phenotypes can change soil processes and biotic communities, whereas soil gradients and microbial communities can influence the expression and evolution of plant phenotypes (Van Nuland et al. 2016). When exterior $\mathrm{N}$ and $\mathrm{P}$ are input into local ecosystem, the given balance between soils, plants and microbes will be destroyed, and a new balance will be formed. For example, in a 50-year-old fertilization experiment, the composition of soil nitrate-reducing, denitrifying and total bacterial communities co-varied with primary production and both were strongly linked to soil properties (Hallin et al. 2009). In paddy soils, Bai et al. (2015) reported that anammox was more common and active in alkaline soils than in acidic soils, and the anammox activities were likely to be regulated by soil chemical properties such as $\mathrm{pH}$, salinity and redox potential.

Soil microbes are mainly consisted of bacteria, fungi and Archaea. They are involved in catalyzing the transitions between compounds of N, P and C, benefiting the plant uptake and microbial propagation (Van Nuland et al. 2016; Zhang et al. 2017). In a paddy soil, the application of organic fertilizer increased the abundance of the copiotrophic bacteria such as Proteobacteria phylum, and the relative abundance of Agaricomycetes and Orbiliomycetes classes of fungi (Wang et al. 2017b). In an arable soil, arbuscular mycorrhiza fungi (AMF) diversity and richness significantly decreased under long-term P fertilizations (Lin et al. 2012). In a temperate steppe in Inner Mongolia, $\mathrm{N}$ fertilization changed ammonia-oxidizing bacteria 
81 (AOB) community composition and increased AOB abundance in both May and August, but

82 significantly decreased ammonia-oxidizing archaea (AOA) abundance in May (Chen et al. 2014).

83 In a temperate desert, nitrogen fertilization increased the relative abundance of Ascomycota

84 phylum and decreased Actinobacteria phylum in spring (Huang et al. 2018). Such changes in soil

85 microbe communities induced by environmental changes might have detrimental effects on the

86 relationship between soil microbes and the plants, and thus negatively influence the productivity.

87 For example, the changes in the fungal to bacterial $(\mathrm{F}: \mathrm{B})$ ratio in the soil microbial biomass can

88 lead to increases in total microbial community $\mathrm{C}: \mathrm{N}$ and declines in biomass turnover rates, both

89 of which can reduce microbial $\mathrm{N}$ uptake (Waring et al. 2013). The decrease of AMF diversity

90 and abundance after fertilization will limit plant nutrient uptake under low soil phosphorus and

91 drought conditions (Wu et al. 2011a).

92 The marker gene amplification metagenomics represent an important way to acquire

93 information on the microbial communities present in complex environments like soil (Lombard

94 et al. 2011), which allow to identify soil microbes that are unable to be cultured in medium.

95 Marker gene amplification metagenomics, typically using the $16 \mathrm{~S}$ and 18S ribosomal RNA, have

96 been applied in studying the uncultured microbial populations in various environments

97 (Handelsman 2009; Oulas et al. 2015). Therefore, in the current study, using high-throughput

98 sequencing technique, we analyzed the soil microbe communities including bacteria and fungi in

99 soils of a degraded steppe which has been fertilized for consecutively three years. The responses

100 of the microbial biomass nitrogen (MBN) and microbial biomass carbon (MBC) as well as the

101 aboveground biomass and the soil chemical properties to fertilizations were also measured. The 
102 main objective of the current study was to clarify how the soil microbe communities respond to 103 three years' fertilization on a degraded arid steppe and their relationship with soil chemical 104 properties and aboveground biomass.

105

106 
107

108

109

110

111

112

113

114 115

116

117

118

119

120

121

122

123

124

125

126

127

\section{METHODS}

\section{Study site}

The experimental site is located in Arigalangtu $\left(43^{\circ} 50^{\prime} 23^{\prime \prime} \mathrm{N} ; 116^{\circ} 09^{\prime} 57^{\prime \prime} \mathrm{E}\right), 15 \mathrm{~km}$ away from Xilinhaote, Inner Mongolia, China. Average annual precipitation is $350 \mathrm{~mm}$ and average annual temperature is $1.7^{\circ} \mathrm{C}$ during the last 50 years, whereas the precipitation in 2014,2015 and 2016 were $255 \mathrm{~mm}, 412 \mathrm{~mm}$ and $309 \mathrm{~mm}$, respectively. The vegetation is a typical steppe, located in an open high plain with altitude reaching approximately $1290 \mathrm{~m}$. Based on plant species investigation, Stipa krylovii is the dominant species, dry weight of which accounts for ca. $68 \%$, followed by Allium bidentatum and Leymus chinensis, accounting for ca. 18\%, with the remaining consisting of Convolvulus ammannii, Cleistogenes squarrosa, Salsola collina, Agropyron michnoi, and Carex korshinskyi, et al.. The soil is mainly light Kastanozems (FAO soil classification). Soil texture averages $21 \%$ clay, $30 \%$ silt and $49 \%$ sand. This area has been continuously grazed by sheep and cattle for at least 20 years before 2014, showing severe deleterious symptoms, mainly low plant productivity and low plant coverage, typical in the most degraded steppes in Inner Mongolia (Pei et al. 2008; Schönbach et al. 2011).

In June 2014, about $50 \mathrm{~km}^{2}$ of this degraded steppe were fenced and excluded from grazing. Soils $(0-20 \mathrm{~cm})$ were sampled and analyzed for basic chemical properties. The concentrations of alkali dispersed $\mathrm{N}(\mathrm{AN})$, available phosphorus (AP, Olsen-P) and available potassium (AK) were 69.79, 3.32 and $133.07 \mathrm{mg} \mathrm{kg}^{-1}$, respectively. The concentrations of total nitrogen (TN), total phosphorus (TP), total potassium (TK), and organic carbon (OC) were 1.16, 0.34, 16.21, and $17.75 \mathrm{~g} \mathrm{~kg}^{-1}$. The soil $\mathrm{pH}$ was 7.75 (soil : water $=1: 5$ ). 
128

129

130

131

132

133

134

135

136

137

138

139

140

141

142

143

144

145

146

148

\section{Experimental design} alcohol ( 70\%) ) solution.

\section{Collection of soil samples}

The experiment was a completely randomized design with five fertilization treatments, 0 (Control), $60 \mathrm{~kg} \mathrm{P} \mathrm{ha}^{-1}(\mathrm{P}), 100 \mathrm{~kg} \mathrm{~N} \mathrm{ha}^{-1}(\mathrm{~N}), 100 \mathrm{~kg} \mathrm{~N} \mathrm{ha}^{-1}$ plus $60 \mathrm{~kg} \mathrm{P} \mathrm{ha}^{-1}$ (NP), and $4000 \mathrm{~kg}$ sheep manure ha ${ }^{-1}\left(\mathrm{M}\right.$, equaling $16.4 \mathrm{~kg} \mathrm{P} \mathrm{ha}^{-1}$ and $\left.81.2 \mathrm{~kg} \mathrm{~N} \mathrm{ha}^{-1}\right)$. The inorganic phosphorus fertilizer was superphosphate $(14 \% \mathrm{P})$; the nitrogen fertilizer was urea $(46 \% \mathrm{~N})$; the sheep manures were collected from farmer's feedlot and composted for 3 months (April to June), air dried, and sieved $(<2 \mathrm{~mm})$ before being applied to the field. Each treatment replicated three times with random complete block design. Each plot size reached $400 \mathrm{~m}^{2}(20 \mathrm{~m} \times 20 \mathrm{~m})$.

Fertilizers were applied on steppe surface in rainy day for three times with once in each year, July 2014, June 2015 and June 2016. The steppes were cut for hay once a year at the end of growing season in late August and early September each year.

\section{Aboveground biomass and root samples}

Aboveground biomass was measured in each month during the growing season, June, July and August of 2016. In each of the sampling plot, plants were cut at the ground level from three quadrats $(1 \mathrm{~m} \times 1 \mathrm{~m})$, dried at $75^{\circ} \mathrm{C}$ for $48 \mathrm{~h}$, and weighed. Meanwhile, fine roots from three plant species, Cleistogenes squarrosa, Stipa krylovii and Leymus chinensis, were sampled, cleaned, and stored in FAA ( $5 \mathrm{~mL}$ formalin (38\% formaldehyde $)+5 \mathrm{~mL}$ acetic acid $+90 \mathrm{~mL}$

After the aboveground biomass were harvested, soil samples were collected in June (before 
149 fertilization), July (one month after fertilization) and August (two month after fertilization)

150 2016.In total, nine soil cores (6 cm in diameter) from 3 quadrats in each plot were collected at 0-

$151 \quad 10 \mathrm{~cm}$ and 10-20 $\mathrm{cm}$ soil layers in each month, bulked into one composite soil sample for each

152 plot from each soil layer. The soils were further divided into two parts, part one was air-dried,

153 sieved to $2 \mathrm{~mm}$ for soil chemical property analysis, part two was stored in $4{ }^{\circ} \mathrm{C}$ for $\mathrm{MBC}$ and 154 MBN analysis. For soil samples in July 2016, ca. $100 \mathrm{~g}$ of fresh soil per sample was stored at $155-80{ }^{\circ} \mathrm{C}$ for DNA extraction. July was the growing month that most plant species were in their 156 vigorous growth stage.

\section{Soil chemical analysis}

158 Organic carbon (OC) was determined by oxidation with potassium dichromate in a concentrated 159 sulfuric acid medium and the excess dichromate was measured using Mohr's salt $\left(\mathrm{K}_{2} \mathrm{Cr}_{2} \mathrm{O}_{7^{-}}\right.$ $\mathrm{H}_{2} \mathrm{SO}_{4}$ ) (Yeomans and Bremner 1988). Dried soils (1.000 g) were digested in $5 \mathrm{~mL} \mathrm{H}_{2} \mathrm{SO}_{4}$ and then determined for soil total nitrogen (TN) by Kjeldahl method (Bao 2005). Total phosphorus (TP) was measured using $\mathrm{NaOH}$ fusion and $\mathrm{Mo}-\mathrm{Sb}$ colorimetric procedure (Bao 2005). Total potassium was measured using $\mathrm{NaOH}$ fusion and flame photometry (Bao 2005). Dried soils $(2.500 \mathrm{~g})$ were mixed and shaken in $50 \mathrm{~mL} 0.5 \mathrm{~mol} \mathrm{~L}^{-1} \mathrm{NaHCO}_{3}$ for $30 \mathrm{~min}$, and then the supernatant was analyzed for available phosphorus (AP) using Mo-Sb colorimetric procedure (Bao 2005). Dried soils (2.000 g) were digested in $10 \mathrm{~mL} 1 \mathrm{~mol} \mathrm{~L}^{-1} \mathrm{NaOH}$ solution for $24 \mathrm{~h}$ and titrated with $0.01 \mathrm{~mol} \mathrm{~L}^{-1} 1 / 2 \mathrm{H}_{2} \mathrm{SO}_{4}$ for alkali dispelled nitrogen (AN) (Bao 2005). Dried soils $(5.000 \mathrm{~g})$ were digested in $50 \mathrm{~mL} 1 \mathrm{~mol} \mathrm{~L}-1 \mathrm{NH}_{4} \mathrm{Ac}$ solution for $15 \mathrm{~min}$, and then the supernatant was analyzed for available potassium (AK) using flame photometer method (Bao 2005). Soil pH 
170

171

172

173

174

175

176

177

178

179

180

181

182

183

184

185

186

187

188

189

value was determined in a soil: water solution (1:5) using a pH meter (Bao 2005).

The soil microbial biomass carbon (MBC) and microbial biomass nitrogen (MBN) was

measured by fumigation-extraction procedure (Brookes et al. 1985). Ten grams of fresh soil samples fumigated with chloroform and non-fumigated were extracted with $50 \mathrm{ml}$ of $0.5 \mathrm{~mol} \mathrm{~L}^{-1}$

$\mathrm{K}_{2} \mathrm{SO}_{4}$ separately. Total carbon and nitrogen in the subsequent filtrates were measured by the methods used for soil samples as mentioned above.

$$
M B C=(A-\mathrm{B}) \div 0.38
$$

A: extractable organic $\mathrm{C}$ in fumigated.

B: extractable organic $\mathrm{C}$ non-fumigated soil.

0.38: The conversion factor for microbial biomass carbon.

$M B N=(C-D) \div 0.45$

$\mathrm{C}$ : extractable organic $\mathrm{N}$ in fumigated.

D: extractable organic $\mathrm{N}$ non-fumigated soil.

0.45: The conversion factor for microbial biomass nitrogen.

\section{Assessment of AMF colonization}

Approximately $2 \mathrm{~g}$ of fine roots were cut into $1 \mathrm{~cm}$ pieces, cleared in $2 \% \mathrm{KOH}(\mathrm{w} / \mathrm{v})$ at $90{ }^{\circ} \mathrm{C}$ for $60 \mathrm{~min}$ and rinsed three times in water on a fine sieve. The root samples were acidified in $2 \%$ $\mathrm{HCl}(\mathrm{v} / \mathrm{v})$ for $30 \mathrm{~min}$ and then stained in $0.05 \%(\mathrm{w} / \mathrm{v})$ trypan blue in lactoglycerol for $30 \mathrm{~min}$ at $90{ }^{\circ} \mathrm{C}$. Root segments of each species were selected randomly from the stained samples. Four 
190

191

192

193

194

195

196

197

198

199

200

201

202

203

204

205

206

207

208

209

210

replicates of 15 roots per slide were assessed for the presence or absence of AMF structures (arbuscules, vesicles and thick hyphae) using a stereomicroscope. AMF colonization was distinguished from non-mycorrhizal fungi as described by Callaway et al. (2003). Colonization was expressed as mycorrhizal frequency $(\mathrm{F} \%)$, mycorrhizal intensity $(\mathrm{M} \%)$ and arbuscular density (A\%) according to the method of Trouvelot et al. (1986).

\section{DNA extraction and PCR amplification}

Microbial DNA was extracted from 30 samples using the E.Z.N.A.® Kit (Omega Bio-tek, Norcross, GA, U.S.) according to manufacturer's protocols. The V3-V4 region of the bacteria 16S ribosomal RNA gene were amplified by PCR $\left(95^{\circ} \mathrm{C}\right.$ for $3 \mathrm{~min}$, followed by $27 / 35$ cycles at $95{ }^{\circ} \mathrm{C}$ for $30 \mathrm{~s}, 55^{\circ} \mathrm{C}$ for $30 \mathrm{~s}$, and $72{ }^{\circ} \mathrm{C}$ for $45 \mathrm{~s}$ and a final extension at $72{ }^{\circ} \mathrm{C}$ for $10 \mathrm{~min}$, $10^{\circ} \mathrm{C}$ until halted by user) using primers 338F (5'-ACTCCTACGGGAGGCAGCA-3') and 806R (5'-ATGCAGGGACTA CHVGGGTWTCTAAT-3'). The fungal sequence of 18S rRNA genes was amplified using primers SSU0817F (5'-TTAGCATGGAATAATRRAATAGGA-3') and SSU1196R (5'-TCTGGACCTGGTGAGTTTCC-3'). PCR reactions were performed in triplicate $20 \mu \mathrm{L}$ mixture containing $4 \mu \mathrm{L}$ of $5 \times$ FastPfu Buffer, $2 \mu \mathrm{L}$ of $2.5 \mathrm{mM}$ dNTPs, $0.8 \mu \mathrm{L}$ of each primer $(5 \mu \mathrm{M}), 0.4 \mu \mathrm{L}$ of FastPfu Polymerase, and $10 \mathrm{ng}$ of template DNA. Bacterial and fungal PCR products were pooled separately to be sequenced in their runs.

\section{Illumina MiSeq sequencing}

Amplicons were extracted from 2\% agarose gels and purified using the AxyPrep DNA Gel Extraction Kit (Axygen Biosciences, Union City, CA, U.S.) according to the manufacturer's instructions and quantified using QuantiFluor ${ }^{\mathrm{TM}}$-ST (Promega, U.S.). Purified amplicons were 
211 pooled in equimolar and paired-end sequenced $(2 \times 300)$ on an Illumina MiSeq platform

212 (Illumina, San Diego,USA) according to the standard protocols. All the sequences of bacteria

213 and fungi were deposited into the NCBI Sequence Read Archive database (SRP126759).

\section{Statistical analysis}

215 Raw fastq files were demultiplexed, quality-filtered by Trimmomatic and merged by FLASH

216 with the following criteria: (i) The reads were truncated at any site receiving an average quality

217 score $<20$ over a 50 bp sliding window. (ii) Primers were exactly matched allowing 2 nucleotide

218 mismatching, and reads containing ambiguous bases were removed. (iii) Sequences whose

219 overlap longer than $10 \mathrm{bp}$ were merged according to their overlap sequence. Operational

220 Taxonomic Units (OTUs) were clustered with 97\% similarity cutoff using UPARSE (version 7.1

221 http://drive5.com/uparse/) and chimeric sequences were identified and removed using UCHIME.

222 The OTU representative sequences were analyzed by RDP Classifier (http://rdp.cme.msu.edu/)

223 against the silva (SSU123)16S rRNA database using confidence threshold of 70\% (Amato et al.

224 2013), while the representative sequences of the fungi were analyzed using UNITE database

225 (Abarenkov et al. 2010).

226 The alpha and beta diversity analyses were performed using the high quality sequences. To

227 assess the diversity of the samples, we used the observed richness estimator Sobs, the coverage

228 estimator Ace, the richness estimator Chao1, the Good's coverage and the Shannon and Simpson

229 diversity indices. To determine the effects of fertilization regimes on bacterial and fungal

230 community compositions, permutational multivariate analysis was performed using the 'vegan'

231 package in $\mathrm{R}$ software (Team 2014). The correlation analysis of the relative abundance of the 
232 bacterial and fungal taxa was held at a phylum level (abundance of the top 50 species) using the

233 R package.

234 Statistical analyses were performed with SPSS 17.0 (SPSS, Inc., Chicago, IL, USA). Results 235 were expressed as mean \pm standard error (SE). Nonparametric variables were mathematically 236 transformed to improve symmetry. The correlation between relative abundance of certain 237 OTU/genus/phylum and environmental factors was performed by Spearman's correlation 238 analyses. $P<0.05$ was considered to be statistically significant according to least significant 239 difference test. The Glomeromycota sequences were aligned and tested using the best-fit model 240 with MEGA 4.0 (Tamura et al. 2007). For the phylogenetic analysis, the maximum likelihood 241 method (Nei and Kumar 2000) was used to construct the tree with MEGA 4.0 using DNA 242 sequences selected according to their sequence similarity to the reference data in GenBank. 


\section{RESULTS}

246 Soil chemical properties and aboveground biomass

247 The contents of soil OC and TN showed no significant difference between fertilization 248 treatments at $0-10 \mathrm{~cm}$ or $10-20 \mathrm{~cm}$ and in three sampling months (Table 1). The ratios of $\mathrm{C} / \mathrm{N}$ 249 ranged from 6.61 to 13.84 and their responses to fertilization differed between sampling months 250 and soil layers. At $0-10 \mathrm{~cm}$ soil layer, $\mathrm{C} / \mathrm{N}$ ratio in non-fertilized plots was higher than those in fertilized plot in June, lower than those in $\mathrm{P}$ and $\mathrm{N}$ fertilized plots in July, and unchanged in August. The contents of AN changed insignificantly after fertilization and varied slightly between months, with the AN contents at 0-10 cm soil layer higher than those at 10-20 cm soil layer. The contents of AP were lower than $5 \mathrm{mg} \mathrm{kg}^{-1}$ in non-fertilized plots in all sampling months, which increased after phosphorus or manure fertilization. The AP contents at $0-10 \mathrm{~cm}$ soil layer were higher than those at $10-20 \mathrm{~cm}$ soil layer. The soil $\mathrm{pH}$ level ranged from 7.37 to 7.85 at $0-10 \mathrm{~cm}$ soil layer and from 7.71 to 8.19 at $10-20 \mathrm{~cm}$ soil layer. Overall, though fertilizations had a trend in increasing the aboveground biomass in all sampling months, no significant difference could be observed between fertilized and non-fertilized plots (Table 2).

\section{Soil microbial biomass carbon and nitrogen}

The influences of fertilizations on $\mathrm{MBC}$ and $\mathrm{MBN}$ varied between treatments and soil layers

(Fig.1). Overall, the $\mathrm{MBC}$ and $\mathrm{MBN}$ at $0-10 \mathrm{~cm}$ soil layer were higher than those at $10-20 \mathrm{~cm}$ soil layer. Phosphorus, nitrogen and manure fertilizations increased the MBC and MBN contents in all sampling months, excepting for insignificant changes of $\mathrm{MBC}$ in manure fertilized plot in 
266 soil layer excepting NP treatment. In June, the MBC in N, NP and manure fertilized plots 267 showed no significant differences, which were significantly lower than those in P fertilized plots 268 at both soil layers. In July, the MBC in manure fertilized plots was significantly lower than those 269 in P, N and NP fertilized plots at both soil layers. In August, the MBC in N and P fertilized plots 270 was the highest and that in manure plots was the lowest at 0-10 $\mathrm{cm}$ soil layer, whereas the MBC 271 in P fertilized plot was significantly higher than those in other treatments at $10-20 \mathrm{~cm}$ soil layer.

272 The MBN was the highest in manure fertilized plots at both soil layers in June, showed no 273 difference between treatments in July excepting for higher MBN in NP plot at 10-20 $\mathrm{cm}$ soil 274 layer, and was the highest in NP plot at both soil layers in August. The ratio between MBC and 275 MBN was all larger than 2. At 0-10 cm soil layer, the ratio increased in fertilized plots excepting 276 for manure fertilized plots in all sampling months and NP fertilized plot in August. At 10-20 cm 277 soil layer, the ratio increased only in P plots in June, in P, N and NP plots in July, and in P and N 278 plots in August.

Biodiversity and abundance of bacterial and fungi

280 In this study, 16S rRNA genes were used as phylogenetic makers to determine changes in bacterial and fungi community structure. In total 1,120,431 bacterial sequences and 1,129,387 fungi sequences were obtained from 30 soil samples, which were further clustered into 3927 OTU for bacteria and 453 OTU for fungi, according to 97\% similarities. Based on these OTUs, the Richness estimator, Ace and Chao, and diversity index, Shannon and Simpson, were further analyzed (Table 3). Overall, the Ace and Chao of bacteria were all larger than 2400, which were almost 10 times of those of fungi. No significant differences of richness estimators could be 
287 observed for bacteria and fungi at both soil layers. The Shannon index of bacteria ranged from

2886.16 to 6.49 for bacteria, significantly higher than those for fungi which were all lower than 3.5.

289 The Simpson index of fungi ranged from 5.93 to 9.05 , significantly higher than those of bacteria

290 which were all lower than 0.8. Bacteria had higher Shannon index and lower Simpson index at 0-

$29110 \mathrm{~cm}$ soil layer than those at $10-20 \mathrm{~cm}$ soil layer, whereas no obvious difference could be 292 observed for fungi.

293 Cluster analysis based on sequencing data of bacteria and fungi indicated that manure

294 fertilization had the greatest influence on soil microbe communities (Fig.2). The soil bacterial

295 sequences in manure fertilized plots were separated with those in the other treatments at both soil

296 layers. For fungi, sequences in phosphorus fertilized plot were separated with other treatments at

297 0-10 cm soil layer, while those in manure fertilized plots were separated with other treatments at

$298 \quad$ 10-20 cm soil layer.

299 Communities of soil bacteria and fungi

300 In the tested soils, the dominant bacteria species with abundance larger than $1 \%$ included Actinobacteria (42.21\%), Proteobacteria (18.44\%), Acidobacteria (15.71\%), Chloroflexi

Bacteroidetes (1.79\%), and Nitrospirae (1.34\%) (Fig.3A, Fig.S1). At 0-10 cm soil layer, manure fertilization had a trend in reducing the abundance of Nitrospirae $(\mathrm{P}<0.05)$ and increasing the abundance of Proteobacteria $(P<0.05)$ (Table S1). At 10-20 $\mathrm{cm}$ soil layer, the abundance of Chloroflexi in manure fertilized plot was significantly higher than those in nonfertilized, P, N and NP fertilized plots. 
308

309

310

311

312

313

314

315

316

317

318

319

320

321

322

323

324

325

326

327

328

The dominant fungi species with abundance larger than $1 \%$ included Ascomycota

$(71.26 \%)$, Basidiomycota (13.50\%), Glomeromycota (4.67\%), Zygomycota (4.56\%),

Ciliophora (1.60\%), Chytridiomycota (1.25\%) (Fig.3B, Fig.S2) . At 0-10 cm soil layer, the abundance of Ciliophora was the highest in manure fertilized plot $(P<0.05)$ (Table S2). At 10$20 \mathrm{~cm}$ soil layer, the abundance of Chytridiomycota increased in P and NP treatments when compared with the non-fertilized plot, whereas unchanged in $\mathrm{N}$ and $\mathrm{M}$ treatments.

\section{AMF colonization and diversity}

The fungi sequences were further blasted in NCBI and seven sequences matched with the published AMF sequences (Fig.4). Cluster analysis separated these sequences into two groups, with MF 693140 clustered with paraglomus occultum in one group, and the other six sequences in another group. MF693141 was clustered with Ambispora fennica; MF693144 was clustered with Scutellospora species; MF693143 and MF693138 were clustered with Rhizophagus species; MF693139 was clustered with Diversispora species; MF693142 was clustered with Claroideglomus species. The abundance of MF693138 was the highest (Fig.5). P fertilization significantly increased the abundance of MF693138, whereas N, NP or manure fertilization showed no significant difference when compared with the non-fertilized plot at both soil layers. The abundance of other AMF sequences was low and showed no variation between treatments.

AMF colonization was measured in three plant species, C. squarrosa, S. krylovii and $L$. chinensis (Table 4). The colonization (F\%), colonization intensity (M\%) and arbuscular (A\%) varied among sampling months and plant species. Fertilization significantly influenced AMF colonization, however, no similar trend could be observed in different sampling months and 
329

330

331

332

plant species.

\section{Relationship between soil chemical properties and microbial community}

Correlation Heatmap indicated that soil chemical properties significantly influenced the abundance of bacteria and fungi (Fig.6). At 0-10 cm soil layer, cluster analysis separated soil $\mathrm{pH}$ with other environmental factors affecting the microbe abundance. The soil $\mathrm{pH}$ was positively correlated with the abundance of three phyla and negatively correlated with one phylum. The ratio of $\mathrm{MBC} / \mathrm{MBN}$ was positively correlated with the abundance of two phyla and negatively correlated with two phyla. Both $\mathrm{MBC}$ and soil $\mathrm{C} / \mathrm{N}$ were negatively correlated with three phyla. $\mathrm{AN}$ and MBN were further separated with other environmental factors. At 10-20 cm soil layer, MBN influenced more on the bacterial abundance, which was positively correlated with three phyla and negatively correlated with three phyla. $\mathrm{C} / \mathrm{N}$ was positively correlated with two phyla and negatively correlated with three phyla. $\mathrm{MBC} / \mathrm{MBN}, \mathrm{AN}, \mathrm{AP}$ and $\mathrm{pH}$, were all correlated with one phylum, positively or negatively.

At $0-10 \mathrm{~cm}$ soil layer, factors affecting the abundance of fungi were separated into two groups, $\mathrm{pH}$ and other factors. Most of the soil chemical properties negatively influenced the fungi abundance, with the positive correlation was only observed with MBN (two phyla), C/N (one phylum), and MBC (one phylum). There were five and four fungi phyla were negatively correlated with AP and MBC/MBN, respectively. AN had no significant influence on any fungi phylum. At 10-20 cm, factors affecting the abundance of fungi were separated into two groups, with $\mathrm{AN}, \mathrm{MBN}, \mathrm{MBC}$ and $\mathrm{MBC} / \mathrm{MBN}$ in one group and the others in second group. Factors in the first group were all positively correlated with fungi abundance excepting for a negative 
350

351

352

353

354

355

356

357

358

359

360

361

362

363

364

365

366

367

368

369

correlation with AN. Factors in the second group were mainly negatively correlated with the abundance of fungi excepting for a positive correlation with $\mathrm{AP}$ and $\mathrm{pH}$.

\section{Discussion}

Fertilizations have been applied in many ecosystems to improve crop production or soil qualities (Mitran et al. 2016; Paredes et al. 2011). In the tested arid steppes, though the contents of soil AP increased significantly after $\mathrm{P}$, NP or manure fertilizations after three years consecutive fertilizations, the aboveground biomass of the tested steppes was not improved, suggesting that sole fertilization in such ecosystem is not efficient in improving steppe productivity. This, on one hand, might be attributed to the low rainfall during growing season (142 mm from May to July), which limited the fertilizer efficiency (Bai et al. 2007; Fang et al. 2005), and thus the plant growth (Austin 2002; Jobbagy et al. 2002). In a degraded steppe in northern China, Chen et al. (2011) also reported that nitrogen fertilization might only be effective in increasing rangeland production in wet years. On the other hand, fertilization might alter other properties of this ecosystem, such as soil microbe activities, which thus offset the positive effect of the fertilizations (Kautz et al. 2004; Plaza et al. 2004).

During the long-term evolution, the soil microbe and the plant species have adapted to their growing environments, and their adaptation is relatively stable under certain conditions (Lau and Lennon 2011). In differently managed Belgian grasslands, Denef et al. (2009) reported that soil habitats significantly differed in microbial community structure as well as in gram-positive 
bacterial rhizodeposit-C uptake. In the current study, phosphorus, nitrogen and manure

371 fertilizations increased $\mathrm{MBC}$ and $\mathrm{MBN}$, suggesting that the propagation of soil microbes were

372 improved when exterior nutrients were input into the degraded steppes. In a temperate desert,

373 Huang et al. (2018) also reported that nitrogen fertilization increased microbial biomass by $14.0 \%$

374 and fungal biomass by $30.0 \%$ in winter. In central high land soils of Kenya, Kamaa et al. (2011)

375 reported that organic inputs had a positive effect on both bacterial and fungal diversity with or

376 without chemical fertilizers.

In total 3927 OTU for bacteria and 453 OTU for fungi were identified from the tested soils.

Fertilizations had no significant influence on the diversity and richness of soil bacteria or fungi at

both soil layers. However, Wang et al. (2017a) reported that inorganic fertilizer significantly

decreased the Chao and ACE richness indexes of bacterial community, but increased that of the

fungal community. Farmer et al. (2017) reported that long-term fertilizer addition greatly

reduced the population of bacteria as well as its richness in a brown soil. The inconsistency

between our results with these studies might be as a result of the differences in precipitation, soil

type or fertilizer types or rates applied to the soil. In the Gurbantunggut Desert, Northwestern

China, water addition increased bacterial and fungal diversity and abundance in summer but not

in winter and spring (Huang et al. 2018). Francioli et al. (2016) reported that organic fertilization

increased bacterial diversity, and stimulated microbial groups that were known to prefer nutrient-

rich environments. These results suggested that the responses of the abundance of bacteria and 
in manure fertilized plots were separated with other fertilizations at both soil layers, excepting

fungi communities in $\mathrm{P}$ fertilized plots which were separated with other fertilizations at $0-10 \mathrm{~cm}$ soil layer. This suggested that the sensitivities of the steppe soil microbes differed in their responses to soil nutrients and fertilizer types. Wang et al. (2016) reported that the prokaryotic community structure in manure fertilized soil was different from that in $\mathrm{N}$ and $\mathrm{P}$ and $\mathrm{NP}$ fertilized soils. Long-term application of inorganic fertilizer resulted in a decrease of bacterial diversity, whereas manure application increased microbe diversity (Sapp et al. 2015; Sun et al. 2015).

In the present study, high-throughput sequencing revealed that the predominant bacteria phyla were Acidobacteria, Proteobacteria, Actinobacteria and Chloroflexi, accounting for an average $84.63 \%$ of the total bacterial sequences; the predominant fungal phylum was Ascomycota, which accounted for an average $71.26 \%$ of the total fungal sequences. These results were in consistent with the previous studies based on agricultural soils (Feng et al. 2015; Su et al. 2017; Wu et al. 2011b). Further analysis confirmed that the abundance of soil bacteria and fungi phylum differed in their responses to fertilizers. For example, nitrogen fertilization increased the abundance of Nitrospira and gram negative bacteria, among which Nitrifier oxidizes the nitrite into nitrate, benefiting the plant nitrogen use efficiency (Kant 2017). Manure relatively increased the abundance of Proteobacteria, which might be attributed to the higher organic carbon input form manures. Fierer et al. (2007) reported that Proteobacteria, especially the Betaproteobacteria 
412 layer, manure fertilizations relatively increased the abundance of Chloroflexi, facultative

413 anaerobic bacteria, among which Chlorobi has also been shown to respond differently to the $\mathrm{N}$

414 and $\mathrm{P}$ inputs in a steppe ecosystem (Pan et al., 2014). For fungi, manure increased the abundance

415 of Ciliophora, P and NP increased the abundance of Chytridiomycota, and P increased the

416 abundance of AMF MF693138. These fungi might differ in their nutrient requirements during

417 propagation (Dong and Yao 2005; Zhu et al. 2008), and the variations of soil chemical properties

418 caused after fertilization resulted in such response differences.

419 AMF are widely distributed in natural soils, which improve plant nutrient uptake and drought resistances (Valyi et al. 2015; Tilman et al. 1996). In the tested soils, in total seven AMF sequences were identified, being clustered with Paraglomus occultum, Ambispora fennica, Scutellospora species, Rhizophagus species, Diversispora, or Claroideglomus species. Though most of these AMF species were also observed in other steppes (Wang et al. 2014; Hiiesalu et al. 2014), no Glomus species was identified in the tested soils, G. mosseae of which has been reported from all continents except the Antarctic (Guo et al. 2016; Rosendahl et al. 2009), reflecting its wide adaptation and positive roles in different ecosystems (Smith and Read 1997).

427 The possible reason might be related to the soil properties of the current degraded steppe. A study with non-degraded, moderately degraded and severely degraded steppes in Inner Mongolia has shown that different AMF species showed different distributions among steppes, suggesting that both biotic and abiotic factors were important in determining the AMF communities (Tian et 
433 of AMF colonization were also observed between sampling months and fertilizations. However,

434 no similar trend could be observed in different months and plant species. This suggested that the

435 AMF species colonizing each plant might be different between plant species (Guo et al. 2016),

436 which attributed to their response variations to fertilizations.

437 In many ecological systems, soil $\mathrm{pH}$ is a very important ecological factor for soil microbes

438 (Fierer and Jackson 2006; Rousk et al. 2010). Heatmap analysis further indicated that soil pH in

439 the tested steppe was also one of the most important soil properties influencing the abundance of

440 soil bacteria and fungi. Though fertilization had no significant influence on soil $\mathrm{pH}$, soil $\mathrm{pH}$

441 differed between two soil layers, causing the difference of microbial communities. Besides soil

$442 \mathrm{pH}$, other soil chemical properties, such as the concentrations of $\mathrm{AP}, \mathrm{AN}, \mathrm{AK}, \mathrm{C} / \mathrm{N}, \mathrm{MBN}, \mathrm{MBC}$,

443 and MBC/MBN all had positive or negative influences on bacterial and fungi communities.

444 Farmer et al. (2017) reported that soil phosphorus and $\mathrm{pH}$ positively influenced the bacterial

445 richness. In a semi-arid steppe, $\mathrm{N}$ inputs significantly increased the relative abundance of

446 Proteobacteria and Firmicutes but reduced the abundance of Acidobacteria, Nitrospirae and

447 Chloraflexi, whereas P additions significantly affected Armatimonadetes and Chlorobi (Ling et

448 al. 2017). These results suggested that soil bacteria and fungi communities in degraded steppes

449 could be altered by improving the soil chemical properties through fertilizations. During nature

450 restoration the efficiency of nutrient cycling can increase by shift in microorganism composition

451 (Morrien et al. 2017). Three years' fertilization improved soil qualities and altered soil bacteria

452 and fungi communities; however, it is still a long term procedure to restore such degraded steppe

453 into original status, including soil properties (McLauchlan et al. 2006), plant species composition 
454 (Zhan et al. 2007), and the network between soil microbe and plants (Hamonts et al. 2017).

455

456 CONCLUSIONS

457 Fertilizations had no significant influence on the richness and diversity of the bacteria and fungi.

458 However, the abundance of individual bacterial or fungi species was sensitive to fertilizations,

459 particularly to manure application, mainly attributing to the variations of soil chemical properties

460 caused by fertilizations. Fertilization, particularly the $\mathrm{P}$ fertilization, influenced the abundance of

461 the AMF species and the AMF colonization in the tested steppes, suggesting that the AMF

462 diversity was driven by soil properties. Among the soil properties, soil $\mathrm{pH}$ in the tested steppe

463 was one of the most important soil properties influencing the abundance of soil bacteria and

464 fungi. Soil bacteria and fungi communities in degraded steppes could be altered by improving

465 the soil chemical properties through fertilizations. However, it is still not clear whether the

466 alteration of the microbe community is detrimental or beneficial to the degraded arid steppes.

467

468 ACKNOWLEDGEMENTS

469 We appreciate the help from Mr. Jianjun Chen for field sampling and fertilization.

470

471

472 


\section{References}

Abarenkov K, Nilsson RH, Larsson K-H, Alexander IJ, Eberhardt U, Erland S, Hoiland K, Kjoller R, Larsson E, Pennanen T, Sen R, Taylor AFS, Tedersoo L, Ursing BM, Vralstad T, Liimatainen K, Peintner U, Koljalg U (2010) The UNITE database for molecular identification of fungi - recent updates and future perspectives. New Phytologist 186 (2):281-285. doi:10.1111/j.1469-8137.2009.03160.x

Amato KR, Yeoman CJ, Kent A, Righini N, Carbonero F, Estrada A, Gaskins HR, Stumpf RM, Yildirim S, Torralba M, Gillis M, Wilson BA, Nelson KE, White BA, Leigh SR (2013) Habitat degradation impacts black howler monkey (Alouatta pigra) gastrointestinal microbiomes. Isme Journal 7 (7):1344-1353. doi:10.1038/ismej.2013.16

Austin AT (2002) Differential effects of precipitation on production and decomposition along a rainfall gradient in Hawaii. Ecology 83 (2):328-338. doi:10.1890/0012-9658(2002)083[0328:deopop]2.0.co;2

Bai R, Xi D, He JZ, Hu HW, Fang YT, Zhang LM (2015) Activity, abundance and community structure of anammox bacteria along depth profiles in three different paddy soils. Soil Biology \& Biochemistry 91:212-221. doi:10.1016/j.soilbio.2015.08.040

Bai Y, Wu J, Clark CM, Pan Q, Zhang L, Chen S, Wang Q, Han X, Wisley B (2012) Grazing alters ecosystem functioning and $\mathrm{C}: \mathrm{N}: \mathrm{P}$ stoichiometry of grasslands along a regional precipitation gradient. Journal of Applied Ecology 49 (6):1204-1215. doi:10.1111/j.1365-2664.2012.02205.x

Bai Y, Wu J, Pan Q, Huang J, Wang Q, Li F, Buyantuyev A, Han X (2007) Positive linear relationship between productivity and diversity: evidence from the Eurasian Steppe. Journal of Applied Ecology 44 (5):10231034. doi:10.1111/j.1365-2664.2007.01351.x

Balser TC, Firestone MK (2005) Linking microbial community composition and soil processes in a California annual grassland and mixed-conifer forest. Biogeochemistry 73 (2):395-415. doi:10.1007/s10533-004-0372-y

Bao SD (2005) Agricultural chemical analysis of soil. China Agriculture Press, Beijing

Bragazza L, Bardgett RD, Mitchell EAD, Buttler A (2015) Linking soil microbial communities to vascular plant abundance along a climate gradient. New Phytologist 205 (3):1175-1182. doi:10.1111/nph.13116

Brookes PC, Landman A, Pruden G, Jenkinson DS (1985) Chloroform fumigation and the release of soil-nitrogen - a rapid direct extraction method to measure microbial biomass nitrogen in soil. Soil Biology \& Biochemistry 17 (6):837-842. doi:10.1016/0038-0717(85)90144-0

Callaway RM, Mahall BE, Wicks C, Pankey J, Zabinski C (2003) Soil fungi and the effects of an invasive forb on grasses: Neighbor identity matters. Ecology 84 (1):129-135. doi:10.1890/00129658(2003)084[0129:sfateo]2.0.co;2

Chen Q, Hooper DU, Lin S (2011) Shifts in Species Composition Constrain Restoration of Overgrazed Grassland Using Nitrogen Fertilization in Inner Mongolian Steppe, China. Plos One 6 (3):e16909

Chen Y-L, Hu H-W, Han H-Y, Du Y, Wan S-Q, Xu Z-W, Chen B-D (2014) Abundance and community structure of ammonia-oxidizing Archaea and Bacteria in response to fertilization and mowing in a temperate steppe in Inner Mongolia. Fems Microbiology Ecology 89 (1):67-79. doi:10.1111/1574-6941.12336

Denef K, Roobroeck D, Wadu M, Lootens P, Boeckx P (2009) Microbial community composition and rhizodepositcarbon assimilation in differently managed temperate grassland soils. Soil Biology \& Biochemistry 41 (1):144-153. doi:10.1016/j.soilbio.2008.10.008

Dong CH, Yao YJ (2005) Nutritional requirements of mycelial growth of Cordyceps sinensis in submerged culture. Journal of Applied Microbiology 99 (3):483-492. doi:10.1111/j.1365-2672.2005.02640.x

Du B, Zhen L, de Groot R, Goulden CE, Long X, Cao X, Wu R, Sun C (2014) Changing patterns of basic household consumption in the Inner Mongolian grasslands: a case study of policy-oriented adoptive changes in the use of grasslands. Rangeland J 36 (5):505-517. doi:10.1071/rj14021

Fang JY, Piao SL, Zhou LM, He JS, Wei FY, Myneni RB, Tucker CJ, Tan K (2005) Precipitation patterns alter growth of temperate vegetation. Geophysical Research Letters 32 (21). doi:10.1029/2005gl024231

Farmer J, Zhang B, Jin X, Zhang P, Wang J (2017) Long-term effect of plastic film mulching and fertilization on bacterial communities in a brown soil revealed by high through-put sequencing. Arch Agron Soil Sci 63 (2):230-241. doi:10.1080/03650340.2016.1193667

Feng Y, Yu Y, Tang H, Zu Q, Zhu J, Lin X (2015) The contrasting responses of soil microorganisms in two rice cultivars to elevated ground-level ozone. Environmental Pollution 197:195-202. doi:10.1016/j.envpol.2014.11.032 
524

Fierer N, Bradford MA, Jackson RB (2007) Toward an ecological classification of soil bacteria. Ecology 88 (6):13541364. doi:10.1890/05-1839

Fierer N, Jackson RB (2006) The diversity and biogeography of soil bacterial communities. Proceedings of the National Academy of Sciences of the United States of America 103 (3):626-631. doi:10.1073/pnas.0507535103

Francioli D, Schulz E, Lentendu G, Wubet T, Buscot F, Reitz T (2016) Mineral vs. organic amendments: microbial community structure, activity and abundance of agriculturally relevant microbes are driven by long-term fertilization strategies. Front Microbiol 7:16. doi:10.3389/fmicb.2016.01446

Gong XY, Chen Q, Dittert K, Taube F, Lin S (2011) Nitrogen, phosphorus and potassium nutritional status of semiarid steppe grassland in Inner Mongolia. Plant and Soil 340 (1/2):265-278. doi:10.1007/s11104-0100577-x

Guo H, Ye CL, Zhang H, Pan S, Ji YG, Li Z, Liu MQ, Zhou X, Du GZ, Hu F, Hu SJ (2017) Long-term nitrogen \& phosphorus additions reduce soil microbial respiration but increase its temperature sensitivity in a Tibetan alpine meadow. Soil Biology \& Biochemistry 113:26-34. doi:10.1016/j.soilbio.2017.05.024

Guo P, Wang CY, Jia Y, Wang QA, Han GM, Tian XJ (2011) Responses of soil microbial biomass and enzymatic activities to fertilizations of mixed inorganic and organic nitrogen at a subtropical forest in East China. Plant and Soil 338 (1-2):355-366. doi:10.1007/s11104-010-0550-8

Guo Y, Du Q, Li G, Ni Y, Zhang Z, Ren W, Hou X (2016) Soil phosphorus fractions and arbuscular mycorrhizal fungi diversity following long-term grazing exclusion on semi-arid steppes in Inner Mongolia. Geoderma 269:7990. doi:10.1016/j.geoderma.2016.01.039

Hallin S, Jones CM, Schloter M, Philippot L (2009) Relationship between N-cycling communities and ecosystem functioning in a 50-year-old fertilization experiment. Isme Journal 3 (5):597-605. doi:10.1038/ismej.2008.128

Hamonts K, Bissett A, Macdonald BCT, Barton PS, Manning AD, Young A (2017) Effects of ecological restoration on soil microbial diversity in a temperate grassy woodland. Applied Soil Ecology 117:117-128. doi:10.1016/j.apsoil.2017.04.005

Handelsman J (2009) Metagenetics: spending our inheritance on the future. Microbial Biotechnology 2 (2):138-139. doi:10.1111/j.1751-7915.2009.00090_8.x

Hiiesalu I, Partel M, Davison J, Gerhold P, Metsis M, Moora M, Oumlpik M, Vasar M, Zobel M, Wilson SD (2014) Species richness of arbuscular mycorrhizal fungi: associations with grassland plant richness and biomass. New Phytologist 203 (1):233-244. doi:10.1111/nph.12765

Huang G, Li L, Su YG, Li Y (2018) Differential seasonal effects of water addition and nitrogen fertilization on microbial biomass and diversity in a temperate desert. Catena 161:27-36. doi:10.1016/j.catena.2017.09.030

Jobbagy EG, Sala OE, Paruelo JM (2002) Patterns and controls of primary production in the Patagonian steppe: A remote sensing approach. Ecology 83 (2):307-319. doi:10.2307/2680015

Kamaa M, Mburu H, Blanchart E, Chibole L, Chotte JL, Kibunja C, Lesueur D (2011) Effects of organic and inorganic fertilization on soil bacterial and fungal microbial diversity in the Kabete long-term trial, Kenya. Biology and Fertility of Soils 47 (3):315-321. doi:10.1007/s00374-011-0539-3

Kant S (2017) Understanding nitrate uptake, signaling and remobilisation for improving plant nitrogen use efficiency. Seminars in cell \& developmental biology. doi:10.1016/j.semcdb.2017.08.034

Kautz T, Wirth S, Ellmer F (2004) Microbial activity in a sandy arable soil is governed by the fertilization reuirne. European Journal of Soil Biology 40 (2):87-94. doi:10.1016/j.ejsobi.2004.10.001

Lau JA, Lennon JT (2011) Evolutionary ecology of plant-microbe interactions: soil microbial structure alters selection on plant traits. New Phytologist 192 (1):215-224. doi:10.1111/j.1469-8137.2011.03790.x

Lin XG, Feng YZ, Zhang HY, Chen RR, Wang JH, Zhang JB, Chu HY (2012) Long-Term Balanced Fertilization Decreases Arbuscular Mycorrhizal Fungal Diversity in an Arable Soil in North China Revealed by 454 Pyrosequencing. Environ Sci Technol 46 (11):5764-5771. doi:10.1021/es3001695

Ling N, Chen DM, Guo H, Wei JX, Bai YF, Shen QR, Hu SJ (2017) Differential responses of soil bacterial communities to long-term N and P inputs in a semi-arid steppe. Geoderma 292:25-33. doi:10.1016/j.geoderma.2017.01.013 
Lombard N, Prestat E, van Elsas JD, Simonet P (2011) Soil-specific limitations for access and analysis of soil microbial communities by metagenomics. Fems Microbiology Ecology 78 (1):31-49. doi:10.1111/j.15746941.2011.01140.x

McLauchlan KK, Hobbie SE, Post WM (2006) Conversion from agriculture to grassland builds soil organic matter on decadal timescales. Ecological Applications 16 (1):143-153. doi:10.1890/04-1650

Mitran T, Mani PK, Basak N, Mazumder D, Roy M (2016) Long-term manuring and fertilization influence soil inorganic phosphorus transformation vis-a-vis rice yield in a rice-wheat cropping system. Arch Agron Soil Sci 62 (1):1-18. doi:10.1080/03650340.2015.1036747

Morrien E, Hannula SE, Snoek LB, Helmsing NR, Zweers H, de Hollander M, Soto RL, Bouffaud ML, Buee M, Dimmers W, Duyts H, Geisen S, Girlanda M, Griffiths RI, Jorgensen HB, Jensen J, Plassart P, Redecker D, Schmelz RM, Schmidt O, Thomson BC, Tisserant E, Uroz S, Winding A, Bailey MJ, Bonkowski M, Faber JH, Martin F, Lemanceau P, de Boer W, van Veen JA, van der Putten WH (2017) Soil networks become more connected and take up more carbon as nature restoration progresses. Nature Communications 8:10. doi:10.1038/ncomms14349

Nei M, Kumar S (2000) Molecular evolution and phylogenetics. Oxford University Press New York

Oulas A, Pavloudi C, Polymenakou P, Pavlopoulos GA, Papanikolaou N, Kotoulas G, Arvanitidis C, Iliopoulos I (2015) Metagenomics: tools and insights for analyzing next-generation sequencing data derived from biodiversity studies. Bioinformatics and Biology Insights 9:75-88. doi:10.4137/bbi.s12462

Paredes C, Menezes-Blackburn D, Cartes P, Gianfreda L, Luz Mora M (2011) Phosphorus and nitrogen fertilization effect on phosphorus uptake and phosphatase activity in ryegrass and tall fescue grown in a chilean andisol. Soil Science 176 (5):1. doi:10.1097/SS.0b013e3182147fd3

Pei SF, Fu H, Wan CG (2008) Changes in soil properties and vegetation following exclosure and grazing in degraded Alxa desert steppe of Inner Mongolia, China. Agriculture Ecosystems \& Environment 124 (1-2):33-39. doi:10.1016/j.agee.2007.08.008

Plaza C, Hernandez D, Garcia-Gil JC, Polo A (2004) Microbial activity in pig slurry-amended soils under semiarid conditions. Soil Biology \& Biochemistry 36 (10):1577-1585. doi:10.1016/j.soilbio.2004.07.017

Ren Y, Lu Y, Fu B (2016) Quantifying the impacts of grassland restoration on biodiversity and ecosystem services in China: A meta-analysis. Ecological Engineering 95:542-550. doi:10.1016/j.ecoleng.2016.06.082

Rosendahl S, McGee P, Morton JB (2009) Lack of global population genetic differentiation in the arbuscular mycorrhizal fungus Glomus mosseae suggests a recent range expansion which may have coincided with the spread of agriculture. Molecular Ecology 18 (20):4316-4329. doi:10.1111/j.1365-294X.2009.04359.x

Rousk J, Brookes PC, Baath E (2010) Investigating the mechanisms for the opposing pH relationships of fungal and bacterial growth in soil. Soil Biology \& Biochemistry 42 (6):926-934. doi:10.1016/j.soilbio.2010.02.009

Sapp M, Harrison M, Hany U, Charlton A, Thwaites R (2015) Comparing the effect of digestate and chemical fertiliser on soil bacteria. Applied Soil Ecology 86:1-9. doi:10.1016/j.apsoil.2014.10.004

Schönbach P, Wan H, Gierus M, Bai Y, Müller K, Lin L, Susenbeth A, Taube F (2011) Grassland responses to grazing: effects of grazing intensity and management system in an Inner Mongolian steppe ecosystem. Plant and Soil 340 (1/2):103-115. doi:10.1007/s11104-010-0366-6

Smith S, Read D (1997) Mycorrhizal symbiosis. 2nd edn. Academic Press, London

Su J, Li X, Yang H (2014) Effects of fertilization on population density and productivity of herbaceous plants in desert steppe. Sciences in Cold and Arid Regions 6 (3):219-225

Su P, Lou J, Brookes PC, Luo Y, He Y, Xu J (2017) Taxon-specific responses of soil microbial communities to different soil priming effects induced by addition of plant residues and their biochars. Journal of Soils and Sediments 17 (3):674-684. doi:10.1007/s11368-015-1238-8

Sun R, Zhang X-X, Guo X, Wang D, Chu H (2015) Bacterial diversity in soils subjected to long-term chemical fertilization can be more stably maintained with the addition of livestock manure than wheat straw. Soil Biology \& Biochemistry 88:9-18. doi:10.1016/j.soilbio.2015.05.007

Symstad AJ, Jonas JL (2011) Incorporating biodiversity into rangeland health: plant species richness and diversity in great plains grasslands. Rangeland Ecology \& Management 64 (6):555-572. doi:10.2111/rem-d-10-00136.1

Tamura K, Dudley J, Nei M, Kumar S (2007) MEGA4: Molecular Evolutionary Genetics Analysis (MEGA) software version 4.0. Molecular Biology and Evolution 24:1596-1599

Team RC (2014) R: A language and environment for statistical computing. R Foundation for Statistical Computing, Vienna, Austria. . 
628

terHorst CP, Lennon JT, Lau JA (2014) The relative importance of rapid evolution for plant-microbe interactions depends on ecological context. Proc R Soc B-Biol Sci 281 (1785):8. doi:10.1098/rspb.2014.0028

Tian H, Gai JP, Zhang JL, Christie P, Li XL (2009) Arbuscular mycorrhizal fungi in degraded typical steppe of Inner Mongolia. Land Degrad Dev 20 (1):41-54. doi:10.1002/Idr.876

Tilman D, Wedin D, Knops J (1996) Productivity and sustainability influenced by biodiversity in grassland ecosystems. Nature 379 (6567):718-720

Trouvelot A, Fardeau JC, Plenchette C, Gianinazzi S, Gianinazzapearson V (1986) Nutritional balance and symbiotic expression in mycorrhizal wheat. Physiologie Vegetale 24 (2):300-300

Valyi K, Rillig MC, Hempel S (2015) Land-use intensity and host plant identity interactively shape communities of arbuscular mycorrhizal fungi in roots of grassland plants. New Phytologist 205 (4):1577-1586. doi:10.1111/nph.13236

Van Nuland ME, Wooliver RC, Pfennigwerth AA, Read QD, Ware IM, Mueller L, Fordyce JA, Schweitzer JA, Bailey JK (2016) Plant-soil feedbacks: connecting ecosystem ecology and evolution. Functional Ecology 30 (7):10321042. doi:10.1111/1365-2435.12690

Wang J, Song Y, Ma T, Raza W, Li J, Howland JG, Huang Q, Shen Q (2017a) Impacts of inorganic and organic fertilization treatments on bacterial and fungal communities in a paddy soil. Applied Soil Ecology 112:4250. doi:10.1016/j.apsoi1.2017.01.005

Wang JC, Song Y, Ma TF, Raza W, Li J, Howland JG, Huang QW, Shen QR (2017b) Impacts of inorganic and organic fertilization treatments on bacterial and fungal communities in a paddy soil. Applied Soil Ecology 112:4250. doi:10.1016/j.apsoi1.2017.01.005

Wang Q, Bao YY, Liu XW, Du GX (2014) Spatio-temporal dynamics of arbuscular mycorrhizal fungi associated with glomalin-related soil protein and soil enzymes in different managed semiarid steppes. Mycorrhiza 24 (7):525-538. doi:10.1007/s00572-014-0572-9

Wang Y, Ji HF, Gao CQ (2016) Differential responses of soil bacterial taxa to long-term P, N, and organic manure application. Journal of Soils and Sediments 16 (3):1046-1058. doi:10.1007/s11368-015-1320-2

Waring BG, Averill C, Hawkes CV (2013) Differences in fungal and bacterial physiology alter soil carbon and nitrogen cycling: insights from meta-analysis and theoretical models. Ecology Letters 16 (7):887-894. doi:10.1111/ele.12125

Wu FS, Dong MX, Liu YJ, Ma XJ, An LZ, Young JPW, Feng HY (2011a) Effects of long-term fertilization on AM fungal community structure and Glomalin-related soil protein in the Loess Plateau of China. Plant and Soil 342 (1-2):233-247. doi:10.1007/s11104-010-0688-4

Wu M, Qin H, Chen Z, Wu J, Wei W (2011b) Effect of long-term fertilization on bacterial composition in rice paddy soil. Biology and Fertility of Soils 47 (4):397-405. doi:10.1007/s00374-010-0535-z

Yang Z, van Ruijven J, Du G (2011) The effects of long-term fertilization on the temporal stability of alpine meadow communities. Plant and Soil 345 (1-2):315-324. doi:10.1007/s11104-011-0784-0

Yeomans JC, Bremner JM (1988) A rapid and precise method for routine determination of organic carbon in soil. Communications in Soil Science and Plant Analysis 13:1467-1476

Yu WT, Bi ML, Xu YG, Zhou H, Ma Q, Jiang CM (2013) Microbial biomass and community composition in a Luvisol soil as influenced by long-term land use and fertilization. Catena 107:89-95. doi:10.1016/j.catena.2013.02.010

Zhan X, Li L, Cheng W (2007) Restoration of Stipa kryloviisteppes in Inner Mongolia of China: Assesment of seed banks and vegetation composition. Journal of Arid Environments 68 (2):298-307. doi:10.1016/j.jaridenv.2006.05.012

Zhang Y, Dong SK, Gao QZ, Liu SL, Ganjurjav H, Wang XX, Su XK, Wu XY (2017) Soil bacterial and fungal diversity differently correlated with soil biochemistry in alpine grassland ecosystems in response to environmental changes. Scientific Reports 7:1-10. doi:10.1038/srep43077

Zhao W, Chen S, Han X, Lin G (2009) Effects of long-term grazing on the morphological and functional traits of Leymus chinensis in the semiarid grassland of Inner Mongolia, China. Ecological research 24 (1):99-108

Zhou X, Wang Y, Zhang P, Guo Z, Chu C, Du G (2016) The effects of fertilization on the trait-abundance relationships in a Tibetan alpine meadow community. Journal of Plant Ecology 9 (2):144-152. doi:10.1093/jpe/rtv043

Zhu Y, Pan J, Qiu J, Guan X (2008) Optimization of nutritional requirements for mycelial growth and sporulation of entomogenous fungus Aschersonia aleyrodis webber. Brazilian Journal of Microbiology 39 (4):770-775 
681

682

683

684

685

686

687

688

689

690

691

692

693

694

695

696

697

698

699

700

701

702

703

704

705

706

707

708

709

710

711

712

713

714

715

716

717

718

719

\section{The collected figure captions}

Figure 1. Effects of continuous fertilization on soil microbial biomass $\mathbf{C}$ and microbial biomass $N$ at $0-10 \mathrm{~cm}(\mathrm{~A}, \mathrm{C}, \mathrm{E})$ and $10-20 \mathrm{~cm}(\mathrm{~B}, \mathrm{D}, \mathrm{F})$ soil layers. CK, Control; P, $60 \mathrm{~kg} \mathrm{P}$ $\mathrm{ha}^{-1}$; N, $100 \mathrm{~kg} \mathrm{~N}$ ha $^{-1}$; NP, $60 \mathrm{~kg} \mathrm{P} \mathrm{ha-1} \mathrm{plus} 100 \mathrm{~kg} \mathrm{~N} \mathrm{ha}^{-1}$; M, $4000 \mathrm{~kg}$ sheep manure ha ${ }^{-1}$. Data were the average of three replicates $( \pm \mathrm{SE})$. Different lowercase letters above the data bar represented significance at $P<0.05$ level (1.s.d).

Figure 2. Overall structural changes of bacterial communities (A) and fungi communities (B) from sequencing data as influenced by fertilizations. The clustering was based on the weighted distance tree in Unifrac. CK, Control; P, $60 \mathrm{~kg} \mathrm{P} \mathrm{ha}^{-1} ; \mathrm{N}, 100 \mathrm{~kg} \mathrm{~N} \mathrm{ha}^{-1}$; NP, $60 \mathrm{~kg} \mathrm{P}$ ha $^{-1}$ plus $100 \mathrm{~kg} \mathrm{~N} \mathrm{ha}^{-1}$; M, $4000 \mathrm{~kg}$ sheep manure ha-1. Lowercase letter " $\mathrm{u}$ " after treatment represented samples from 0-10 cm soil layer; "d" represented samples from 10-20 cm soil layer.

Figure 3. Proportions of the bacterial phyla (A) and fungal phyla (B) with the relative abundance higher than 1\%. CK, Control; P, $60 \mathrm{~kg} \mathrm{P}^{-1} ; \mathrm{N}, 100 \mathrm{~kg} \mathrm{~N}$ ha ${ }^{-1} ; \mathrm{NP}, 60 \mathrm{~kg} \mathrm{P} \mathrm{ha}^{-1}$ plus $100 \mathrm{~kg} \mathrm{~N} \mathrm{ha-1}$; M, $4000 \mathrm{~kg}$ sheep manure ha-1. Lowercase letter " $u$ " after treatment represented samples from 0-10 cm soil layer; "d" represented samples from 10-20 cm soil layer.

Figure 4. Phylogenetic tree inferred from the fungi sequences of AMF. Numbers above branches indicate the bootstrap support (1000 replicates). Cluster was conducted according to the maximum likelihood method. GenBank accession numbers followed by a black triangle $(\boldsymbol{\Delta})$ represent the sequences obtained in the present study. Names followed by codes represent the sequences downloaded from the GenBank.

Figure 5. Effects of fertilizations on the abundance of $A M F$ in soils at $0-10 \mathrm{~cm}(\mathrm{~A})$ and 10 20 cm (B). CK, Control; P, 60 kg P ha-1; N, 100 kg N ha' ${ }^{-1}$ NP, 60 kg P ha-1 plus 100 kg N ha-1; $\mathrm{M}, 4000 \mathrm{~kg}$ sheep manure ha-1 ${ }^{-1}$ Different lowercase letters above the data bar represented significance at $P<0.05$ level (1.s.d).

Figure 6. Spearman Correlation Heatmap between bacterial and soil properties at 0-10 cm (A) and 10-20 cm (B) and fungi and soil properties at 0-10 cm (C) and 10-20 cm (D). AN, alkaline hydrolyzed N; AP, available P; AK, available potassium; MBC, microbial biomass C; MBN, microbial biomass $\mathrm{N}$. The $\mathrm{R}$ values are displayed in different colors and the right color card of the heat map is a color partition of different $\mathrm{R}$ values. $0.01<P<=0.05 * 0.001<P<=0.01$ ** $P<=0.001 * * *$. CK, Control; P, $60 \mathrm{~kg} \mathrm{P} \mathrm{ha}^{-1}$; N, $100 \mathrm{~kg} \mathrm{~N} \mathrm{ha}^{-1}$; NP, $60 \mathrm{~kg} \mathrm{P} \mathrm{ha}{ }^{-1}$ plus $100 \mathrm{~kg}$ $\mathrm{N} \mathrm{ha}{ }^{-1} ; \mathrm{M}, 4000 \mathrm{~kg}$ sheep manure ha-1. Lowercase letter "u" after treatment represented samples from 0-10 cm soil layer; "d" represented samples from 10-20 cm soil layer. 
720 Fig. S1 Dominant bacteria phyla with abundance larger than 1\%. Averaged across all 721 treatments.

722

723

Fig. S2 Dominant fungi phyla with abundance larger than $1 \%$. Averaged across all

724 treatments.

725

726 


\section{Table $\mathbf{1}$ (on next page)}

Effects of fertilizations on the soil chemical properties.

Different lowercase letters after the data within each soil layer represented significance at $P<0.05$ (I.s.d). De, depth; Tr, treatment. CK, Control; P, $60 \mathrm{~kg} \mathrm{P} \mathrm{ha}^{-1} ; \mathrm{N}, 100 \mathrm{~kg} \mathrm{~N}^{-1} ; \mathrm{NP}, 60$ $\mathrm{kg} \mathrm{P} \mathrm{ha}^{-1}$ plus $100 \mathrm{~kg} \mathrm{~N} \mathrm{ha}^{-1} ; \mathrm{M}, 4000 \mathrm{~kg}$ sheep manure ha-1. OC, organic C; TN, total N; AN, alkali dispelled $\mathrm{N}$; $\mathrm{AP}$, available $\mathrm{P}$. Values were the means of three replicates $\pm \mathrm{SE}$. 
Table 1

Effects of fertilizations on the soil chemical properties. Different lowercase letters after the data within each soil layer represented significance at $P<0.05$ (1.s.d). De, depth; Tr, treatment. CK, Control; P, 60 kg P ha-1 N, $100 \mathrm{~kg} \mathrm{~N} \mathrm{ha}^{-1}$; NP, $60 \mathrm{~kg} \mathrm{P} \mathrm{ha}^{-1}$ plus $100 \mathrm{~kg} \mathrm{~N} \mathrm{ha}^{-1} ; \mathrm{M}, 4000 \mathrm{~kg}$ sheep manure ha- ${ }^{-1}$ OC, organic C; TN, total N; AN, alkali dispelled N; AP, available P. Values were the means of three replicates $\pm \mathrm{SE}$.

\begin{tabular}{|c|c|c|c|c|c|c|c|}
\hline De & $\operatorname{Tr}$ & $\begin{array}{c}\mathrm{OC} \\
\mathrm{g} \mathrm{kg}^{-1}\end{array}$ & $\begin{array}{c}\mathrm{TN} \\
\mathrm{g} \mathrm{kg}^{-1}\end{array}$ & $\mathrm{C} / \mathrm{N}$ & $\begin{array}{c}\mathrm{AN} \\
\mathrm{mg} \mathrm{kg}^{-1}\end{array}$ & $\begin{array}{c}\mathrm{AP} \\
\mathrm{mg} \mathrm{kg}^{-1}\end{array}$ & $\mathrm{pH}$ \\
\hline \multicolumn{8}{|c|}{ June 2016} \\
\hline $0-$ & $\mathrm{CK}$ & $10.09 \pm 0.23 \mathrm{a}$ & $0.87 \pm 0.02 \mathrm{a}$ & $11.57 \pm 0.05 \mathrm{a}$ & $98.70 \pm 1.21 \mathrm{a}$ & $3.58 \pm 1.31 \mathrm{c}$ & $7.83 \pm 0.11 \mathrm{a}$ \\
\hline 10 & $\mathrm{P}$ & $9.69 \pm 0.23 \mathrm{a}$ & $0.98 \pm 0.03 \mathrm{a}$ & $9.92 \pm 0.36 \mathrm{~b}$ & $100.80 \pm 5.28 \mathrm{a}$ & $14.43 \pm 0.51 \mathrm{a}$ & $7.75 \pm 0.09 a$ \\
\hline \multirow[t]{3}{*}{$\mathrm{cm}$} & $\mathrm{N}$ & $10.85 \pm 0.68 \mathrm{a}$ & $1.07 \pm 0.02 \mathrm{a}$ & $10.13 \pm 0.57 b$ & $103.60 \pm 2.80 \mathrm{a}$ & $6.33 \pm 2.35 b c$ & $7.58 \pm 0.16 \mathrm{a}$ \\
\hline & NP & $9.96 \pm 0.13 \mathrm{a}$ & $1.16 \pm 0.01 \mathrm{a}$ & $8.59 \pm 0.13 \mathrm{c}$ & $107.10 \pm 3.21 \mathrm{a}$ & $13.91 \pm 0.55 \mathrm{a}$ & $7.75 \pm 0.09 a$ \\
\hline & M & $10.80 \pm 0.29 a$ & $1.12 \pm 0.02 \mathrm{a}$ & $9.67 \pm 0.17 b$ & $101.50 \pm 12.38 \mathrm{a}$ & $10.48 \pm 3.27 \mathrm{ab}$ & $7.82 \pm 0.06 \mathrm{a}$ \\
\hline $10-$ & $\mathrm{CK}$ & $8.34 \pm 0.59 \mathrm{a}$ & $0.88 \pm 0.06 \mathrm{a}$ & $9.56 \pm 0.56 \mathrm{ab}$ & $79.80 \pm 4.85 \mathrm{a}$ & $1.83 \pm 0.80 \mathrm{~b}$ & $7.99 \pm 0.09 a$ \\
\hline 20 & $\mathrm{P}$ & $7.77 \pm 0.29 \mathrm{a}$ & $0.91 \pm 0.05 \mathrm{a}$ & $8.53 \pm 0.17 b c$ & $83.13 \pm 3.20 \mathrm{a}$ & $6.25 \pm 1.09 \mathrm{a}$ & $7.71 \pm 0.12 \mathrm{a}$ \\
\hline \multirow[t]{4}{*}{$\mathrm{cm}$} & $\mathrm{N}$ & $8.38 \pm 0.09 \mathrm{a}$ & $0.94 \pm 0.03 \mathrm{a}$ & $8.97 \pm 0.36 \mathrm{bc}$ & $72.80 \pm 1.40 \mathrm{a}$ & $4.17 \pm 0.36 \mathrm{ab}$ & $7.82 \pm 0.09 \mathrm{a}$ \\
\hline & NP & $7.67 \pm 0.01 \mathrm{a}$ & $0.92 \pm 0.01 \mathrm{a}$ & $8.33 \pm 0.11 \mathrm{c}$ & $86.63 \pm 6.26 \mathrm{a}$ & $2.83 \pm 0.36 \mathrm{ab}$ & $8.02 \pm 0.12 \mathrm{a}$ \\
\hline & M & $9.52 \pm 0.12 \mathrm{a}$ & $0.91 \pm 0.02 \mathrm{a}$ & $10.45 \pm 0.38 \mathrm{a}$ & $72.80 \pm 1.40 \mathrm{a}$ & $3.67 \pm 2.10 \mathrm{ab}$ & $8.04 \pm 0.08 \mathrm{a}$ \\
\hline & & & & July 2016 & & & \\
\hline $0-$ & $\mathrm{CK}$ & $10.51 \pm 0.40 \mathrm{a}$ & $1.05 \pm 0.02 \mathrm{a}$ & $10.00 \pm 0.47 \mathrm{c}$ & $88.90 \pm 9.42 \mathrm{a}$ & $2.92 \pm 0.10 \mathrm{c}$ & $7.85 \pm 0.19 a$ \\
\hline 10 & $\mathrm{P}$ & $12.13 \pm 0.47 \mathrm{a}$ & $0.88 \pm 0.001 \mathrm{a}$ & $13.84 \pm 0.55 \mathrm{a}$ & $97.30 \pm 3.90 \mathrm{a}$ & $19.44 \pm 1.83 \mathrm{a}$ & $7.75 \pm 0.14 \mathrm{a}$ \\
\hline \multirow[t]{3}{*}{$\mathrm{cm}$} & $\mathrm{N}$ & $12.44 \pm 0.18 \mathrm{a}$ & $1.03 \pm 0.05 \mathrm{a}$ & $12.15 \pm 0.64 b$ & $98.70 \pm 9.15 \mathrm{a}$ & $3.79 \pm 0.83 \mathrm{c}$ & $7.37 \pm 0.15 \mathrm{a}$ \\
\hline & NP & $12.13 \pm 0.83 \mathrm{a}$ & $1.18 \pm 0.04 \mathrm{a}$ & $10.28 \pm 0.61 \mathrm{c}$ & $109.90 \pm 5.47 \mathrm{a}$ & $11.25 \pm 2.66 \mathrm{~b}$ & $7.59 \pm 0.16 \mathrm{a}$ \\
\hline & M & $10.83 \pm 0.18 \mathrm{a}$ & $1.19 \pm 0.05 \mathrm{a}$ & $9.12 \pm 0.21 \mathrm{c}$ & $93.10 \pm 8.94 \mathrm{a}$ & $4.23 \pm 1.51 \mathrm{c}$ & $7.63 \pm 0.15 \mathrm{a}$ \\
\hline $10-$ & $\mathrm{CK}$ & $9.46 \pm 0.24 \mathrm{a}$ & $0.88 \pm 0.02 \mathrm{a}$ & $10.71 \pm 0.12 \mathrm{a}$ & $72.10 \pm 2.80 \mathrm{a}$ & $2.52 \pm 0.12 b$ & $8.05 \pm 0.12 \mathrm{a}$ \\
\hline 20 & $\mathrm{P}$ & $9.60 \pm 0.14 \mathrm{a}$ & $0.85 \pm 0.03 \mathrm{a}$ & $11.32 \pm 0.47 \mathrm{a}$ & $74.90 \pm 9.10 \mathrm{a}$ & $4.16 \pm 0.38 \mathrm{a}$ & $8.19 \pm 0.16 \mathrm{a}$ \\
\hline \multirow[t]{4}{*}{$\mathrm{cm}$} & $\mathrm{N}$ & $9.77 \pm 0.65 \mathrm{a}$ & $0.91 \pm 0.01 \mathrm{a}$ & $10.74 \pm 0.78 \mathrm{a}$ & $77.70 \pm 9.92 \mathrm{a}$ & $2.15 \pm 0.34 b$ & $7.86 \pm 0.03 \mathrm{a}$ \\
\hline & NP & $8.53 \pm 0.42 \mathrm{a}$ & $1.00 \pm 0.03 \mathrm{a}$ & $8.55 \pm 0.29 b$ & $89.60 \pm 6.22 \mathrm{a}$ & $2.75 \pm 0.66 b$ & $8.04 \pm 0.09 \mathrm{a}$ \\
\hline & M & $10.38 \pm 0.65 \mathrm{a}$ & $0.99 \pm 0.06 \mathrm{a}$ & $10.51 \pm 0.31 \mathrm{a}$ & $90.3 \pm 10.57 \mathrm{a}$ & $1.98 \pm 0.19 b$ & $8.00 \pm 0.07 \mathrm{a}$ \\
\hline & & & & August 2016 & & & \\
\hline $0-$ & $\mathrm{CK}$ & $9.25 \pm 0.05 \mathrm{a}$ & $1.26 \pm 0.03 \mathrm{a}$ & $7.37 \pm 0.18 \mathrm{a}$ & $92.17 \pm 6.27 \mathrm{a}$ & $3.38 \pm 0.57 \mathrm{c}$ & $7.78 \pm 0.12 \mathrm{a}$ \\
\hline 10 & $\mathrm{P}$ & $11.32 \pm 0.08 \mathrm{a}$ & $1.23 \pm 0.01 \mathrm{a}$ & $9.23 \pm 0.14 \mathrm{a}$ & $94.73 \pm 3.06 \mathrm{a}$ & $15.17 \pm 3.47 \mathrm{a}$ & $7.64 \pm 0.10 \mathrm{a}$ \\
\hline \multirow[t]{3}{*}{$\mathrm{cm}$} & $\mathrm{N}$ & $10.29 \pm 0.87 \mathrm{a}$ & $1.42 \pm 0.12 \mathrm{a}$ & $7.28 \pm 0.41 \mathrm{a}$ & $106.6 \pm 15.16 \mathrm{a}$ & $3.22 \pm 0.50 \mathrm{c}$ & $7.45 \pm 0.12 b$ \\
\hline & NP & $9.00 \pm 0.44 \mathrm{a}$ & $1.36 \pm 0.01 \mathrm{a}$ & $6.61 \pm 0.35 \mathrm{a}$ & $107.10 \pm 8.17 \mathrm{a}$ & $11.85 \pm 2.49 \mathrm{ab}$ & $7.44 \pm 0.06 \mathrm{~b}$ \\
\hline & M & $10.15 \pm 0.00 \mathrm{a}$ & $1.23 \pm 0.04 \mathrm{a}$ & $8.29 \pm 0.24 \mathrm{a}$ & $92.26 \pm 2.03 \mathrm{a}$ & $8.17 \pm 2.23 b c$ & $7.49 \pm 0.03 \mathrm{a}$ \\
\hline $10-$ & $\mathrm{CK}$ & $9.50 \pm 0.16 \mathrm{a}$ & $1.09 \pm 0.003 \mathrm{a}$ & $8.75 \pm 0.12 b$ & $80.73 \pm 3.93 \mathrm{a}$ & $2.31 \pm 0.30 \mathrm{c}$ & $8.07 \pm 0.15 \mathrm{a}$ \\
\hline 20 & $\mathrm{P}$ & $10.66 \pm 0.21 \mathrm{a}$ & $1.02 \pm 0.01 \mathrm{a}$ & $10.43 \pm 0.15 b$ & $77.93 \pm 2.63 \mathrm{a}$ & $5.32 \pm 1.64 \mathrm{ab}$ & $8.00 \pm 0.08 \mathrm{a}$ \\
\hline \multirow[t]{3}{*}{$\mathrm{cm}$} & $\mathrm{N}$ & $8.78 \pm 0.32 \mathrm{a}$ & $1.15 \pm 0.07 \mathrm{a}$ & $6.88 \pm 0.21 b$ & $74.20 \pm 10.01 \mathrm{a}$ & $2.28 \pm 0.27 \mathrm{c}$ & $8.04 \pm 0.28 \mathrm{a}$ \\
\hline & NP & $7.91 \pm 0.13 \mathrm{a}$ & $1.12 \pm 0.03 \mathrm{a}$ & $7.06 \pm 0.27 b$ & $72.80 \pm 1.85 \mathrm{a}$ & $7.35 \pm 1.02 \mathrm{a}$ & $7.92 \pm 0.03 \mathrm{a}$ \\
\hline & M & $9.78 \pm 0.02 \mathrm{a}$ & $1.00 \pm 0.05 \mathrm{a}$ & $9.82 \pm 0.50 \mathrm{a}$ & $78.26 \pm 7.40 \mathrm{a}$ & $3.62 \pm 0.18 \mathrm{bc}$ & $7.76 \pm 0.01 \mathrm{a}$ \\
\hline
\end{tabular}




\section{Table 2 (on next page)}

Effects of fertilizations on total aboveground biomass ( $\left.\mathrm{kg} \mathrm{DM} \mathrm{ha}^{-1}\right)$.

Different lowercase letter after the data in each month represented significance at $P<0.05$ level (I.s.d). CK, Control; P, $60 \mathrm{~kg} \mathrm{P} \mathrm{ha-1}^{-1}$ N, $100 \mathrm{~kg} \mathrm{~N} \mathrm{ha}^{-1}$; NP, $60 \mathrm{~kg} \mathrm{P} \mathrm{ha}^{-1}$ plus $100 \mathrm{~kg} \mathrm{~N} \mathrm{ha}^{-1}$; M, $4000 \mathrm{~kg}$ sheep manure ha-1. 
Table 2

Effects of fertilizations on total aboveground biomass ( $\left.\mathrm{kg} \mathrm{DM} \mathrm{ha}^{-1}\right)$. Different lowercase letter after the data in each month represented significance at $P<0.05$ level (l.s.d). CK, Control; P, $60 \mathrm{~kg} \mathrm{P} \mathrm{ha}^{-1}$; N, 100 $\mathrm{kg} \mathrm{N} \mathrm{ha}^{-1} ; \mathrm{NP}, 60 \mathrm{~kg} \mathrm{P} \mathrm{ha}{ }^{-1}$ plus $100 \mathrm{~kg} \mathrm{~N} \mathrm{ha}^{-1} ; \mathrm{M}, 4000 \mathrm{~kg}$ sheep manure ha ${ }^{-1}$.

\begin{tabular}{cccc}
\hline & June & July & August \\
\hline CK & $702.9 \pm 7.42 \mathrm{a}$ & $863.4 \pm 106.9 \mathrm{a}$ & $897.4 \pm 21.1 \mathrm{a}$ \\
$\mathbf{P}$ & $705.3 \pm 53.69 \mathrm{a}$ & $1087.7 \pm 108.9 \mathrm{a}$ & $1095.0 \pm 23.8 \mathrm{a}$ \\
$\mathbf{N}$ & $692.0 \pm 65.0 \mathrm{a}$ & $1062.5 \pm 94.4 \mathrm{a}$ & $937.0 \pm 21.8 \mathrm{a}$ \\
$\mathbf{N P}$ & $755.1 \pm 36.1 \mathrm{a}$ & $1131.0 \pm 46.1 \mathrm{a}$ & $1089.2 \pm 9.5 \mathrm{a}$ \\
$\mathbf{M}$ & $747.3 \pm 79.5 \mathrm{a}$ & $1013.9 \pm 81.8 \mathrm{a}$ & $856.6 \pm 122.2 \mathrm{a}$ \\
\hline
\end{tabular}




\section{Table 3(on next page)}

Diversity indices of soil bacterial and fungi communities in degraded arid steppes as influenced by fertilizations.

Different lowercase letter after the data in each soil layer represented significance at $P<0.05$ level (I.s.d). CK, Control; P, $60 \mathrm{~kg} \mathrm{P} \mathrm{ha}^{-1} ; \mathrm{N}, 100 \mathrm{~kg} \mathrm{~N} \mathrm{ha}^{-1}$; NP, $60 \mathrm{~kg} \mathrm{P} \mathrm{ha}^{-1}$ plus $100 \mathrm{~kg} \mathrm{~N} \mathrm{ha-}{ }^{-1}$; M, $4000 \mathrm{~kg}$ sheep manure ha-1. 
Table 3

Diversity indices of soil bacterial and fungi communities in degraded arid steppes as influenced by fertilizations. Different lowercase letter after the data in each soil layer represented significance at $P<0.05$ level (1.s.d). CK, Control; P, $60 \mathrm{~kg} \mathrm{P} \mathrm{ha}^{-1} ; \mathrm{N}, 100 \mathrm{~kg} \mathrm{~N} \mathrm{ha}^{-1}$; NP, $60 \mathrm{~kg} \mathrm{P} \mathrm{ha}{ }^{-1}$ plus $100 \mathrm{~kg} \mathrm{~N} \mathrm{ha}^{-1}$; M, $4000 \mathrm{~kg}$ sheep manure ha-1.

\begin{tabular}{|c|c|c|c|c|c|c|c|}
\hline & & \multirow[t]{2}{*}{ Treatment } & \multicolumn{2}{|c|}{ Richness estimator } & \multicolumn{2}{|c|}{ Diversity index } & \multirow[b]{2}{*}{ Coverage $(\%)$} \\
\hline & & & Ace & Chao & Shannon & $\operatorname{Simpson}(\%)$ & \\
\hline \multirow[t]{10}{*}{$0-10 \mathrm{~cm}$} & Bacterial & CK & $2752.09 \pm 31.90 \mathrm{a}$ & $2732.96 \pm 44.32 \mathrm{a}$ & $6.49 \pm 0.01 \mathrm{a}$ & $0.45 \pm 0.01 \mathrm{a}$ & 96.97 \\
\hline & & $\mathrm{P}$ & $2695.87 \pm 76.79 \mathrm{a}$ & $2711.19 \pm 82.01 \mathrm{a}$ & $6.42 \pm 0.04 \mathrm{a}$ & $0.48 \pm 0.06 \mathrm{a}$ & 96.96 \\
\hline & & $\mathrm{N}$ & $2654.69 \pm 35.76 \mathrm{a}$ & $2691.37 \pm 33.05 \mathrm{a}$ & $6.36 \pm 0.06 \mathrm{a}$ & $0.52 \pm 0.09 \mathrm{a}$ & 97.02 \\
\hline & & NP & $2626.71 \pm 81.73 a$ & $2635.74 \pm 81.80 \mathrm{a}$ & $6.42 \pm 0.11 \mathrm{a}$ & $0.44 \pm 0.02 \mathrm{a}$ & 97.08 \\
\hline & & M & $2629.60 \pm 29.36 \mathrm{a}$ & $2612.58 \pm 21.75 \mathrm{a}$ & $6.41 \pm 0.05 \mathrm{a}$ & $0.46 \pm 0.08 \mathrm{a}$ & 97.07 \\
\hline & Fungi & $\mathrm{CK}$ & $182.89 \pm 3.20 \mathrm{a}$ & $183.40 \pm 2.76 \mathrm{a}$ & $3.49 \pm 0.06 \mathrm{a}$ & $5.93 \pm 0.81 \mathrm{a}$ & 99.91 \\
\hline & & $\mathrm{P}$ & $164.53 \pm 12.04 \mathrm{a}$ & $167.97 \pm 15.55 \mathrm{a}$ & $3.36 \pm 0.12 \mathrm{a}$ & $6.19 \pm 0.98 \mathrm{a}$ & 99.91 \\
\hline & & $\mathrm{N}$ & $185.92 \pm 8.21 \mathrm{a}$ & $187.41 \pm 8.85 \mathrm{a}$ & $3.32 \pm 0.13 \mathrm{a}$ & $7.38 \pm 1.92 \mathrm{a}$ & 99.9 \\
\hline & & NP & $173.17 \pm 8.04 \mathrm{a}$ & $171.69 \pm 6.77 \mathrm{a}$ & $3.37 \pm 0.05 \mathrm{a}$ & $6.34 \pm 0.74 \mathrm{a}$ & 99.92 \\
\hline & & M & $198.31 \pm 6.25 \mathrm{a}$ & $196.54 \pm 1.24 \mathrm{a}$ & $3.24 \pm 0.31 \mathrm{a}$ & $9.05 \pm 4.44 \mathrm{a}$ & 99.89 \\
\hline \multirow[t]{10}{*}{$10-20 \mathrm{~cm}$} & Bacterial & CK & $2547.23 \pm 47.37 \mathrm{a}$ & $2566.96 \pm 65.75 \mathrm{a}$ & $6.21 \pm 0.03 \mathrm{a}$ & $0.65 \pm 0.06 \mathrm{a}$ & 97.09 \\
\hline & & $\mathrm{P}$ & $2495.59 \pm 88.77 \mathrm{a}$ & $2505.43 \pm 104.85 \mathrm{a}$ & $6.22 \pm 0.06 \mathrm{a}$ & $0.73 \pm 0.10 \mathrm{a}$ & 97.22 \\
\hline & & $\mathrm{N}$ & $2508.50 \pm 57.66 \mathrm{a}$ & $2515.83 \pm 35.21 \mathrm{a}$ & $6.16 \pm 0.11 \mathrm{a}$ & $0.71 \pm 0.15 \mathrm{a}$ & 97.08 \\
\hline & & NP & $2644.51 \pm 2.29 \mathrm{a}$ & $2649.42 \pm 28.10 \mathrm{a}$ & $6.29 \pm 0.05 \mathrm{a}$ & $0.57 \pm 0.05 \mathrm{a}$ & 96.93 \\
\hline & & M & $2644.29 \pm 64.92 \mathrm{a}$ & $2640.09 \pm 78.60 \mathrm{a}$ & $6.30 \pm 0.09 \mathrm{a}$ & $0.56 \pm 0.08 \mathrm{a}$ & 96.97 \\
\hline & Fungi & CK & $158.80 \pm 10.50 \mathrm{a}$ & $161.38 \pm 9.69 \mathrm{a}$ & $3.22 \pm 0.04 \mathrm{a}$ & $7.13 \pm 0.41 \mathrm{a}$ & 99.92 \\
\hline & & $\mathrm{P}$ & $149.36 \pm 5.74 \mathrm{a}$ & $150.86 \pm 7.12 \mathrm{a}$ & $3.38 \pm 0.06 \mathrm{a}$ & $6.24 \pm 0.54$ & 99.95 \\
\hline & & $\mathrm{N}$ & $167.98 \pm 7.79 \mathrm{a}$ & $167.94 \pm 7.30 \mathrm{a}$ & $3.33 \pm 0.09 \mathrm{a}$ & $6.58 \pm 1.05 \mathrm{a}$ & 99.93 \\
\hline & & NP & $167.16 \pm 9.63 \mathrm{a}$ & $165.80 \pm 9.62 \mathrm{a}$ & $3.29 \pm 0.04 \mathrm{a}$ & $7.14 \pm 0.21 \mathrm{a}$ & 99.93 \\
\hline & & M & $178.72 \pm 11.88 \mathrm{a}$ & $176.12 \pm 9.69 \mathrm{a}$ & $3.20 \pm 0.12 \mathrm{a}$ & $8.16 \pm 1.58 \mathrm{a}$ & 99.91 \\
\hline
\end{tabular}




\section{Table 4 (on next page)}

Effects of fertilization on AMF colonization of Cleistogenes squarrosa, Stipa krylovii and Leymus chinensis in different growing months.

F\%: colonization; M\%: colonization intensity; A\%: arbuscular. Different lowercase letter after the data in each soil layer represented significance at $P<0.05$ level (I.s.d). CK, Control; P, 60 $\mathrm{kg} \mathrm{P} \mathrm{ha}^{-1} ; \mathrm{N}, 100 \mathrm{~kg} \mathrm{~N} \mathrm{ha}^{-1} ; \mathrm{NP}, 60 \mathrm{~kg} \mathrm{P} \mathrm{ha}^{-1}$ plus $100 \mathrm{~kg} \mathrm{~N} \mathrm{ha}^{-1} ; \mathrm{M}, 4000 \mathrm{~kg}$ sheep manure ha-1. 
Table 4

Effects of fertilization on AMF colonization of Cleistogenes squarrosa, Stipa krylovii and Leymus chinensis in different growing months. F\%: colonization; M\%: colonization intensity; A\%: arbuscular. Different lowercase letter after the data in each soil layer represented significance at $P<0.05$ level (1.s.d). CK, Control; P, $60 \mathrm{~kg}$ P ha${ }^{1} ; \mathrm{N}, 100 \mathrm{~kg} \mathrm{~N} \mathrm{ha}^{-1} ; \mathrm{NP}, 60 \mathrm{~kg} \mathrm{P} \mathrm{ha}^{-1}$ plus $100 \mathrm{~kg} \mathrm{~N} \mathrm{ha}^{-1} ; \mathrm{M}, 4000 \mathrm{~kg}$ sheep manure ha ${ }^{-1}$.

\begin{tabular}{|c|c|c|c|c|c|c|c|c|c|c|}
\hline \multirow[b]{2}{*}{ Month } & \multirow[t]{2}{*}{ Treatment } & \multicolumn{3}{|c|}{$\mathrm{F} \%$} & \multicolumn{3}{|c|}{$\mathrm{M} \%$} & \multicolumn{3}{|c|}{$\mathrm{A} \%$} \\
\hline & & $\begin{array}{c}\text { Cleistogenes } \\
\text { squarrosa }\end{array}$ & Stipa krylovii & $\begin{array}{c}\text { Leymus } \\
\text { chinensis }\end{array}$ & $\begin{array}{c}\text { Cleistogenes } \\
\text { squarrosa }\end{array}$ & $\begin{array}{c}\text { Stipa } \\
\text { krylovii }\end{array}$ & $\begin{array}{c}\text { Leymus } \\
\text { chinensis }\end{array}$ & $\begin{array}{c}\text { Cleistogenes } \\
\text { squarrosa }\end{array}$ & Stipa krylovii & $\begin{array}{c}\text { Leymus } \\
\text { chinensis }\end{array}$ \\
\hline \multirow[t]{5}{*}{ June } & $\mathrm{CK}$ & $82.67 \pm 2.40 \mathrm{~b}$ & $92.00 \pm 3.06 \mathrm{a}$ & $90.00 \pm 2.31 b$ & $7.59 \pm 1.55 b$ & $13.86 \pm 5.30 \mathrm{a}$ & $12.62 \pm 5.20 \mathrm{~b}$ & $0.52 \pm 0.08 \mathrm{c}$ & $2.16 \pm 0.16 b$ & $0.66 \pm 0.36 \mathrm{c}$ \\
\hline & $\mathrm{P}$ & $82.67 \pm 2.40 \mathrm{~b}$ & $91.33 \pm 3.53 \mathrm{a}$ & $93.33 \pm 3.53 \mathrm{ab}$ & $11.33 \pm 2.26 \mathrm{ab}$ & $13.01 \pm 2.05 \mathrm{a}$ & $13.37 \pm 1.65 \mathrm{~b}$ & $2.79 \pm 0.37 \mathrm{bc}$ & $3.56 \pm 1.15 \mathrm{ab}$ & $3.62 \pm 0.58 \mathrm{bc}$ \\
\hline & $\mathrm{N}$ & $88.67 \pm 2.67 \mathrm{ab}$ & $95.33 \pm 1.33 \mathrm{a}$ & $100.00 \pm 0 \mathrm{a}$ & $17.03 \pm 0.28 \mathrm{a}$ & $21.73 \pm 4.42 \mathrm{a}$ & $20.00 \pm 4.09 \mathrm{ab}$ & $5.41 \pm 1.09 \mathrm{a}$ & $5.45 \pm 1.62 \mathrm{a}$ & $4.70 \pm 1.56 \mathrm{~b}$ \\
\hline & NP & $92.00 \pm 1.15 \mathrm{a}$ & $90.00 \pm 5.03 \mathrm{a}$ & $98.00 \pm 1.15 \mathrm{a}$ & $16.34 \pm 4.99 \mathrm{ab}$ & $8.15 \pm 2.01 \mathrm{a}$ & $18.25 \pm 2.21 \mathrm{ab}$ & $3.73 \pm 1.14 \mathrm{ab}$ & $0.61 \pm 0.06 \mathrm{~b}$ & $5.25 \pm 0.56 b$ \\
\hline & $\mathrm{M}$ & $83.33 \pm 0.67 b$ & $93.33 \pm 1.33 \mathrm{a}$ & $94.67 \pm 1.76 \mathrm{ab}$ & $10.93 \pm 2.30 \mathrm{ab}$ & $13.21 \pm 4.84 \mathrm{a}$ & $29.23 \pm 4.82 \mathrm{a}$ & $0.78 \pm 0.08 \mathrm{c}$ & $1.21 \pm 0.32 b$ & $11.33 \pm 1.89 \mathrm{a}$ \\
\hline \multirow[t]{5}{*}{ July } & $\mathrm{CK}$ & $90.67 \pm 0.67 \mathrm{c}$ & $87.33 \pm 0.67 \mathrm{c}$ & $100.00 \pm 0 \mathrm{a}$ & $18.65 \pm 1.20 \mathrm{~b}$ & $7.13 \pm 0.50 \mathrm{c}$ & $13.09 \pm 0.05 \mathrm{~d}$ & $14.06 \pm 0.56 \mathrm{~b}$ & $0.87 \pm 0.05 \mathrm{c}$ & $5.54 \pm 0.16 \mathrm{~d}$ \\
\hline & $\mathrm{P}$ & $96.67 \pm 0.67 b$ & $100.00 \pm 0 \mathrm{a}$ & $100.00 \pm 0 \mathrm{a}$ & $26.41 \pm 0.54 \mathrm{a}$ & $43.25 \pm 0.95 b$ & $22.11 \pm 1.26 \mathrm{c}$ & $18.14 \pm 1.30 \mathrm{a}$ & $23.05 \pm 0.73 \mathrm{ab}$ & $14.23 \pm 0.18 b$ \\
\hline & $\mathrm{N}$ & $100.00 \pm 0 \mathrm{a}$ & $98.67 \pm 1.33 \mathrm{a}$ & $98.00 \pm 1.15 \mathrm{a}$ & $17.16 \pm 2.13 b$ & $34.79 \pm 8.91 b$ & $34.75 \pm 1.02 \mathrm{a}$ & $5.67 \pm 0.10 \mathrm{c}$ & $17.36 \pm 3.60 \mathrm{~b}$ & $19.82 \pm 0.14 \mathrm{a}$ \\
\hline & NP & $82.67 \pm 0.67 \mathrm{e}$ & $92.00 \pm 1.15 b$ & $90.67 \pm 0.67 b$ & $8.47 \pm 0.30 \mathrm{c}$ & $13.11 \pm 0.50 \mathrm{c}$ & $13.91 \pm 0.14 \mathrm{~d}$ & $3.06 \pm 0.11 \mathrm{~d}$ & $2.04 \pm 0.25 \mathrm{c}$ & $7.00 \pm 0.12 \mathrm{c}$ \\
\hline & M & $88.67 \pm 0.67 d$ & $100.00 \pm 0 \mathrm{a}$ & $98.67 \pm 1.33 \mathrm{a}$ & $3.43 \pm 0.65 \mathrm{~d}$ & $58.17 \pm 0.44 \mathrm{a}$ & $29.80 \pm 1.04 \mathrm{~b}$ & $0.88 \pm 0.20 \mathrm{e}$ & $27.40 \pm 3.25 \mathrm{a}$ & $14.53 \pm 0.19 b$ \\
\hline \multirow[t]{5}{*}{ August } & $\mathrm{CK}$ & $91.67 \pm 0.88 b$ & $87.33 \pm 0.67 \mathrm{~d}$ & $98.67 \pm 1.33 \mathrm{a}$ & $22.63 \pm 2.17 \mathrm{a}$ & $20.95 \pm 3.37 b$ & $26.73 \pm 1.22 b$ & $2.94 \pm 0.58 b$ & $3.68 \pm 1.50 \mathrm{c}$ & $14.51 \pm 0.25 \mathrm{a}$ \\
\hline & $\mathrm{P}$ & $96.67 \pm 0.67 \mathrm{a}$ & $95.33 \pm 0.67 b$ & $98.00 \pm 2.00 \mathrm{a}$ & $22.47 \pm 0.94 \mathrm{a}$ & $36.41 \pm 4.42 \mathrm{a}$ & $30.37 \pm 0.33 \mathrm{a}$ & $16.27 \pm 0.89 a$ & $18.41 \pm 1.63 b$ & $12.00 \pm 0.45 b$ \\
\hline & $\mathrm{N}$ & $88.67 \pm 0.67 \mathrm{c}$ & $95.33 \pm 0.67 b$ & $98.67 \pm 1.33 \mathrm{a}$ & $9.91 \pm 0.54 b$ & $25.68 \pm 0.55 b$ & $8.43 \pm 1.26 \mathrm{~d}$ & $2.91 \pm 0.12 b$ & $3.17 \pm 0.55 \mathrm{c}$ & $6.41 \pm 0.27 \mathrm{~d}$ \\
\hline & $\mathrm{NP}$ & $80.67 \pm 0.67 d$ & $91.33 \pm 0.67 \mathrm{c}$ & $97.33 \pm 1.33 \mathrm{a}$ & $7.67 \pm 0.59 b$ & $23.31 \pm 0.34 b$ & $19.29 \pm 0.13 c$ & $1.22 \pm 0.09 \mathrm{c}$ & $4.38 \pm 0.55 \mathrm{c}$ & $10.82 \pm 0.07 b c$ \\
\hline & $\mathrm{M}$ & $91.33 \pm 0.67 \mathrm{~b}$ & $100.00 \pm 0 \mathrm{a}$ & $96.00 \pm 2.31 \mathrm{a}$ & $24.97 \pm 0.52 \mathrm{a}$ & $40.53 \pm 0.63 \mathrm{a}$ & $22.14 \pm 0.95 \mathrm{c}$ & $3.73 \pm 0.27 \mathrm{~b}$ & $24.76 \pm 0.93 \mathrm{a}$ & $9.97 \pm 0.76 \mathrm{c}$ \\
\hline
\end{tabular}


Figure 1

Effects of continuous fertilization on soil microbial biomass $\mathrm{C}$ and microbial biomass $\mathrm{N}$ at 0-10 cm ( $, C, E)$ and $10-20 \mathrm{~cm}(B, D, F)$ soil layers.

CK, Control; P, $60 \mathrm{~kg} \mathrm{P} \mathrm{ha}^{-1} ; \mathrm{N}, 100 \mathrm{~kg} \mathrm{~N} \mathrm{ha}^{-1} ; \mathrm{NP}, 60 \mathrm{~kg} \mathrm{P} \mathrm{ha}^{-1}$ plus $100 \mathrm{~kg} \mathrm{~N} \mathrm{ha}^{-1} ; \mathrm{M}, 4000 \mathrm{~kg}$ sheep manure ha-1. Data were the average of three replicates $( \pm \mathrm{SE})$. Different lowercase letters above the data bar represented significance at $P<0.05$ level (I.s.d). 

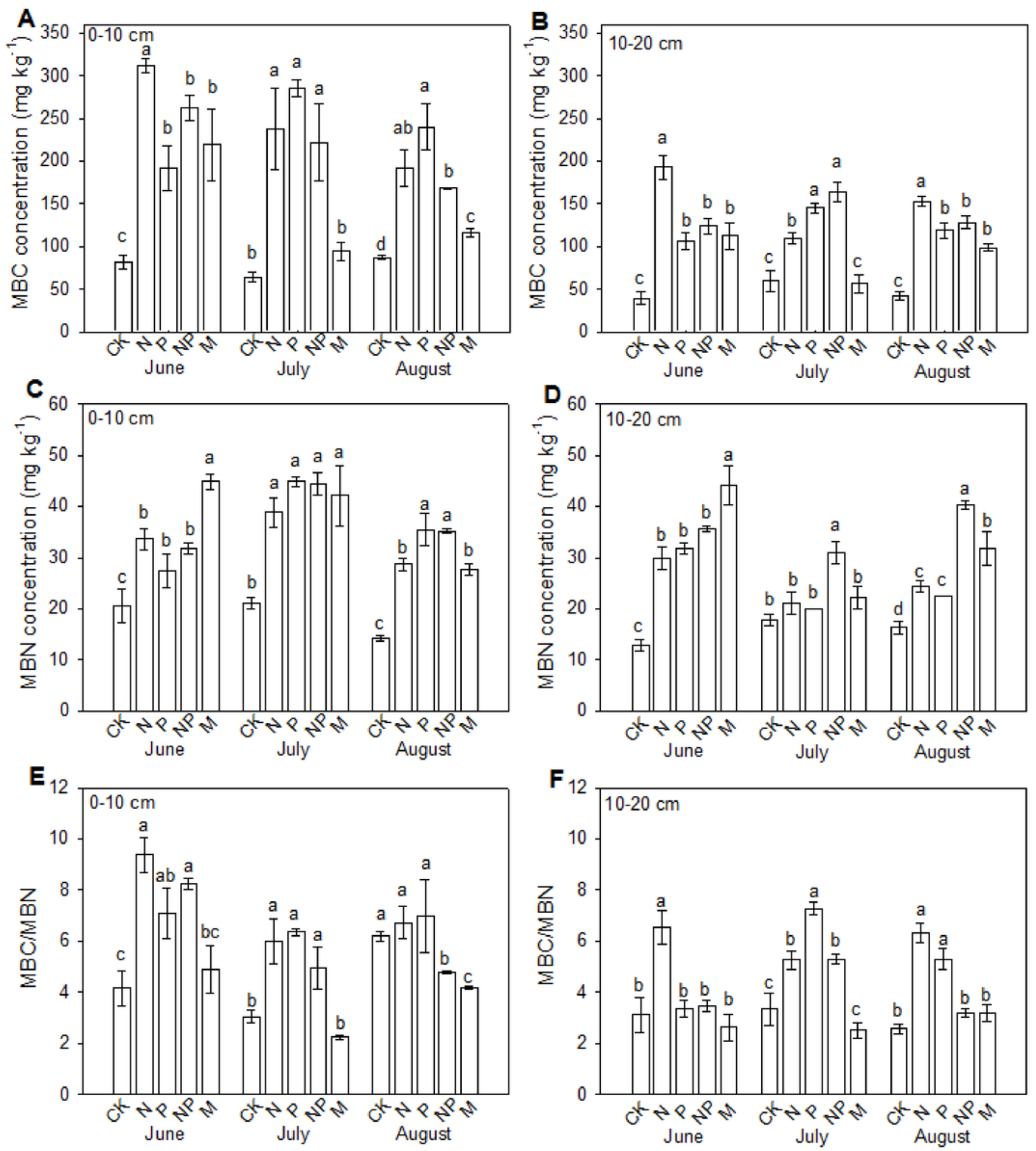
Figure 2

Overall structural changes of bacterial communities (A) and fungi communities (B) from sequencing data as influenced by fertilizations.

The clustering was based on the weighted distance tree in Unifrac. CK, Control; P, $60 \mathrm{~kg} \mathrm{P} \mathrm{ha-}$ ${ }^{1}$; N, $100 \mathrm{~kg} \mathrm{~N} \mathrm{ha}^{-1}$; NP, $60 \mathrm{~kg} \mathrm{P} \mathrm{ha}^{-1}$ plus $100 \mathrm{~kg} \mathrm{~N} \mathrm{ha}^{-1} ; \mathrm{M}, 4000 \mathrm{~kg}$ sheep manure ha-1. Lowercase letter " $u$ " after treatment represented samples from 0-10 cm soil layer; " $d$ " represented samples from $10-20 \mathrm{~cm}$ soil layer.

\section{A: Bacteria community}
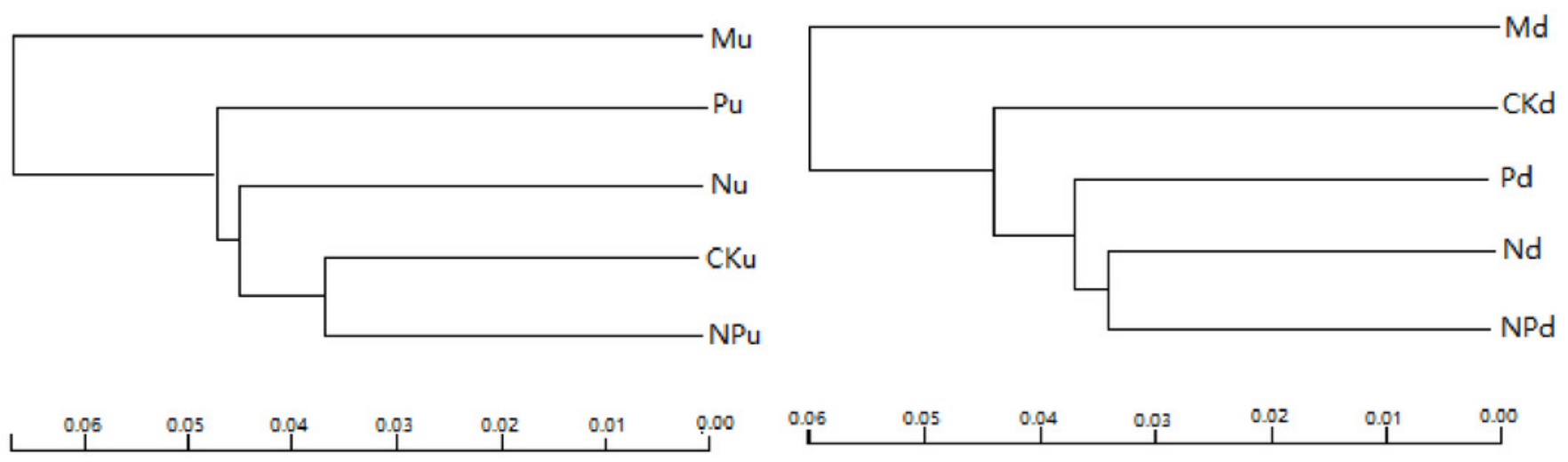

B: Fungi community
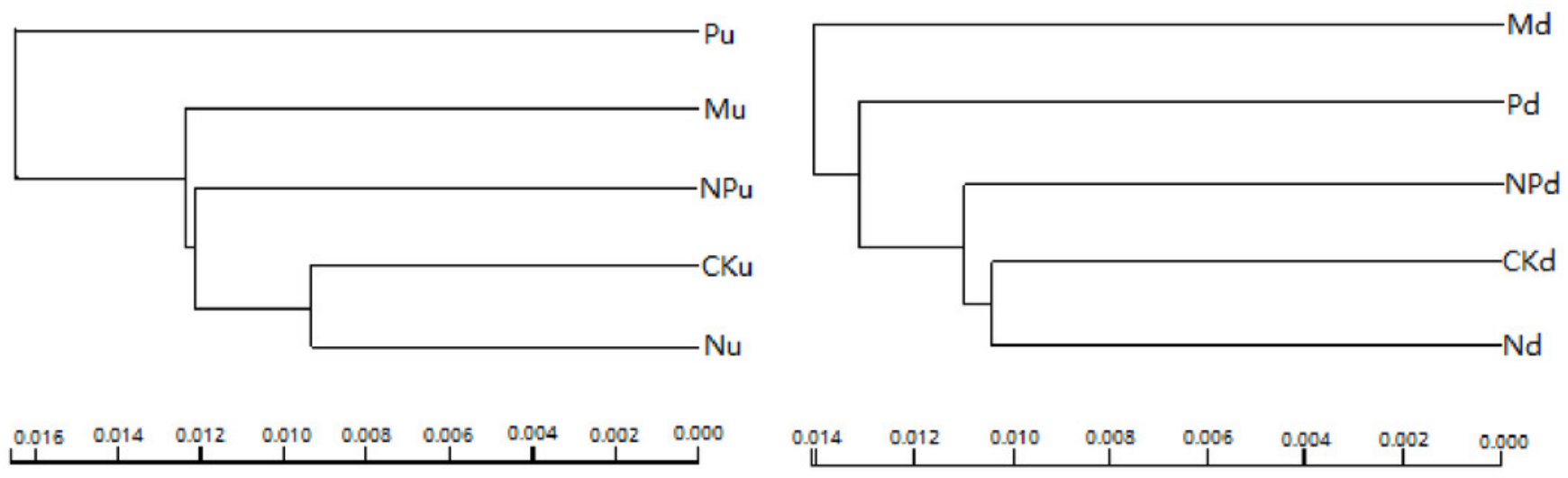
Figure 3

Proportions of the bacterial phyla (A) and fungal phyla (B) with the relative abundance higher than $1 \%$.

CK, Control; P, $60 \mathrm{~kg} \mathrm{P} \mathrm{ha-1;} \mathrm{N,} 100 \mathrm{~kg} \mathrm{~N} \mathrm{ha}^{-1} ; \mathrm{NP}, 60 \mathrm{~kg} \mathrm{P}^{-1}$ has $100 \mathrm{~kg} \mathrm{~N} \mathrm{ha}^{-1} ; \mathrm{M}, 4000 \mathrm{~kg}$ sheep manure ha-1. Lowercase letter " $u$ " after treatment represented samples from 0-10 cm soil layer; " $\mathrm{d}$ " represented samples from $10-20 \mathrm{~cm}$ soil layer. 
A Bacteria phylum

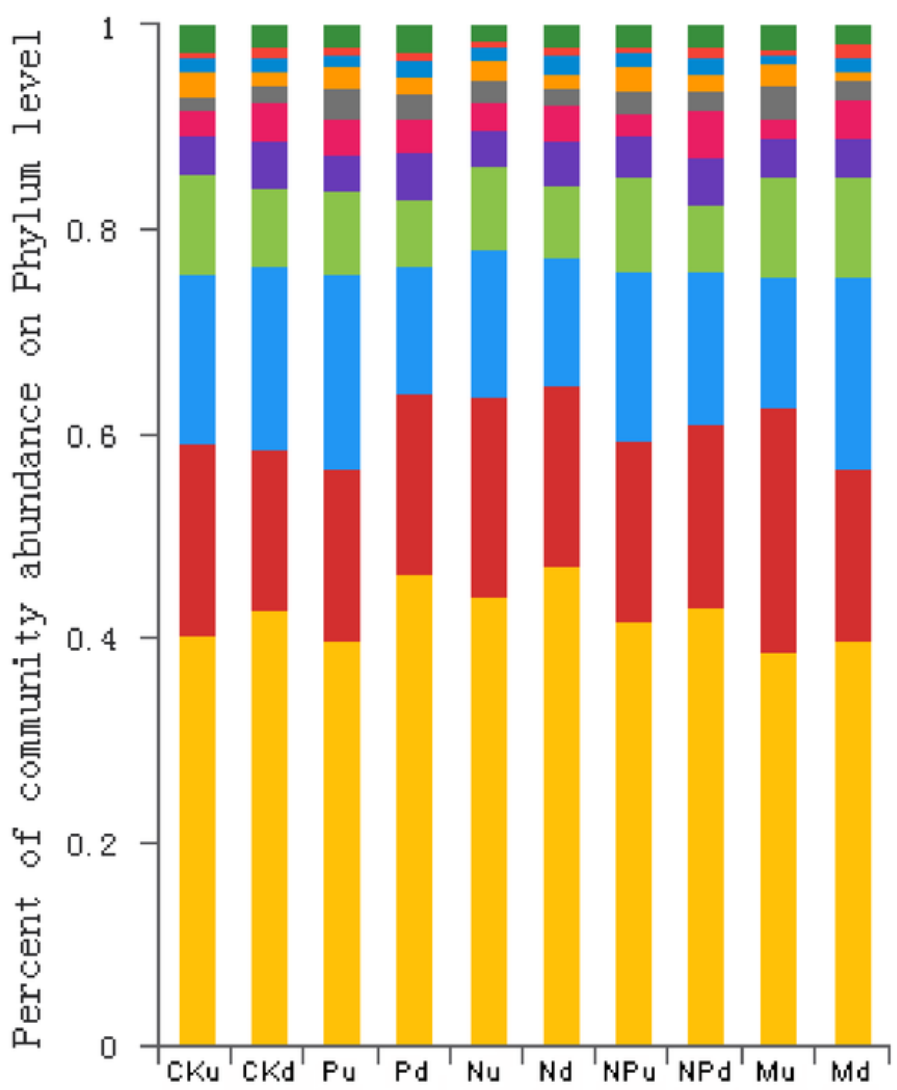

P1 anctongcetes

Ti trospirae

Bacteroi detes

Fireicutes

Yerruconicrobia

Gematimonadetes

Chlor oflexi

Aci dobacteri a

Proteobacteria

hctinobacteria

others

B

Fungi phylum

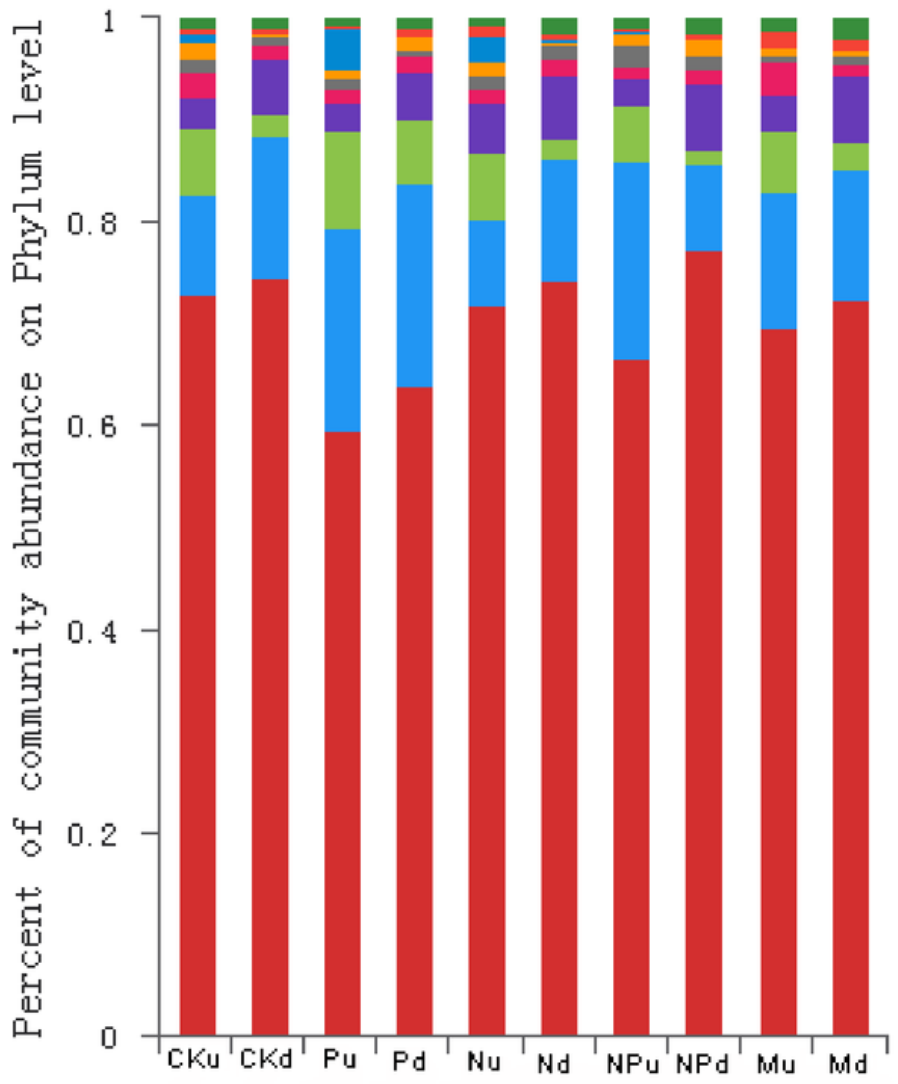

unclassified_k_Fungi

hr thropoda

Chytri di onycota

noclassified_d_Enkaryota

Cili ophor a

Zygonycota

Gloneronycota

Basi di onycota

hsconycota

others 
Figure 4

Phylogenetic tree inferred from the fungi sequences of AMF.

Numbers above branches indicate the bootstrap support (1000 replicates). Cluster was conducted according to the maximum likelihood method. GenBank accession numbers followed by a black triangle $(\boldsymbol{\Lambda})$ represent the sequences obtained in the present study. Names followed by codes represent the sequences downloaded from the GenBank.

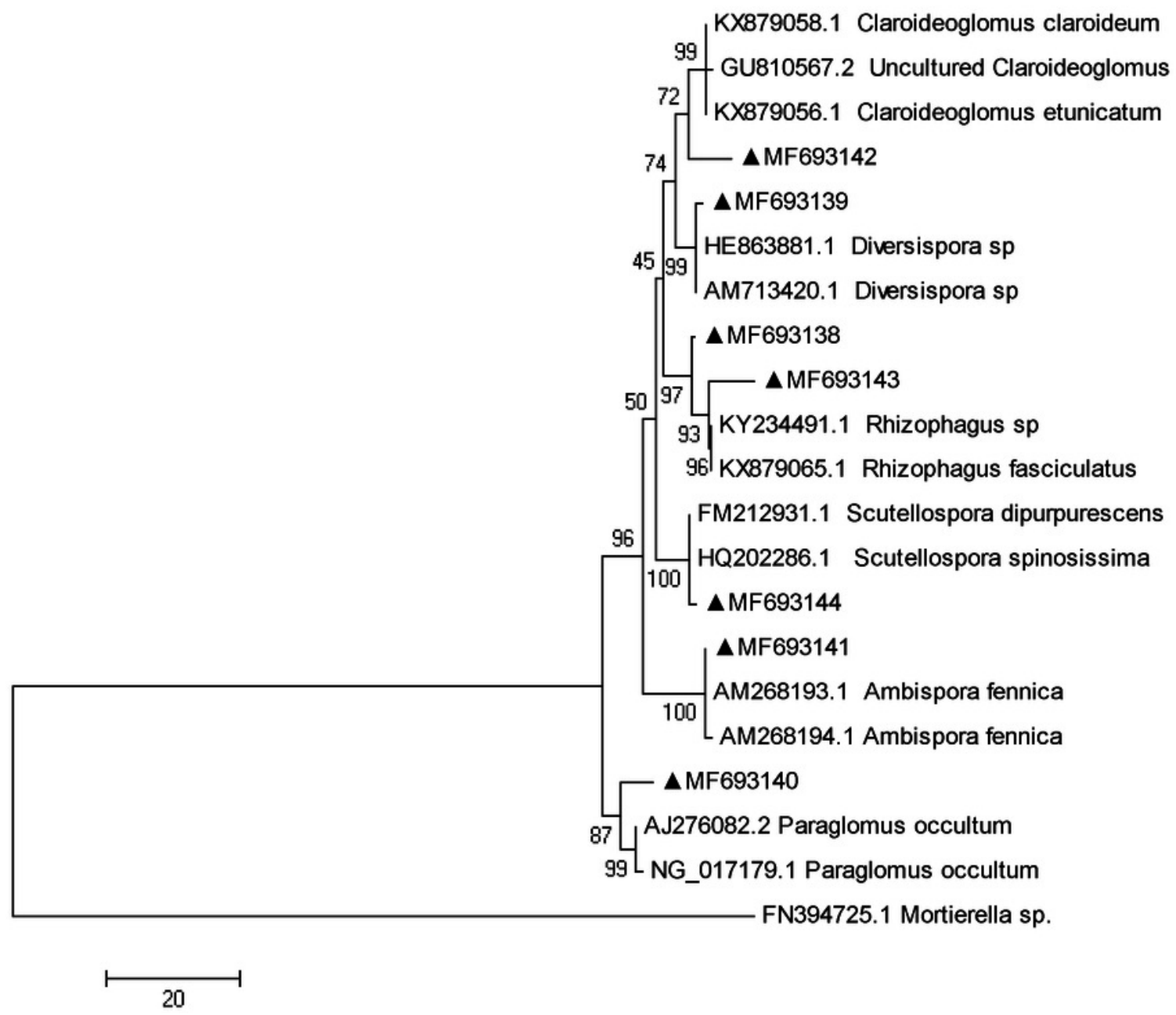




\section{Figure 5}

Effects of fertilizations on the abundance of AMF in soils at $0-10 \mathrm{~cm}(\mathrm{~A})$ and $10-20 \mathrm{~cm}$ (B).

CK, Control; P, $60 \mathrm{~kg} \mathrm{P} \mathrm{ha}^{-1} ; \mathrm{N}, 100 \mathrm{~kg} \mathrm{~N} \mathrm{ha}^{-1} ; \mathrm{NP}, 60 \mathrm{~kg} \mathrm{P} \mathrm{ha}^{-1}$ plus $100 \mathrm{~kg} \mathrm{~N} \mathrm{ha}{ }^{-1} ; \mathrm{M}, 4000 \mathrm{~kg}$ sheep manure ha ${ }^{-1}$. Different lowercase letters above the data bar represented significance at $P<0.05$ level (l.s.d). 

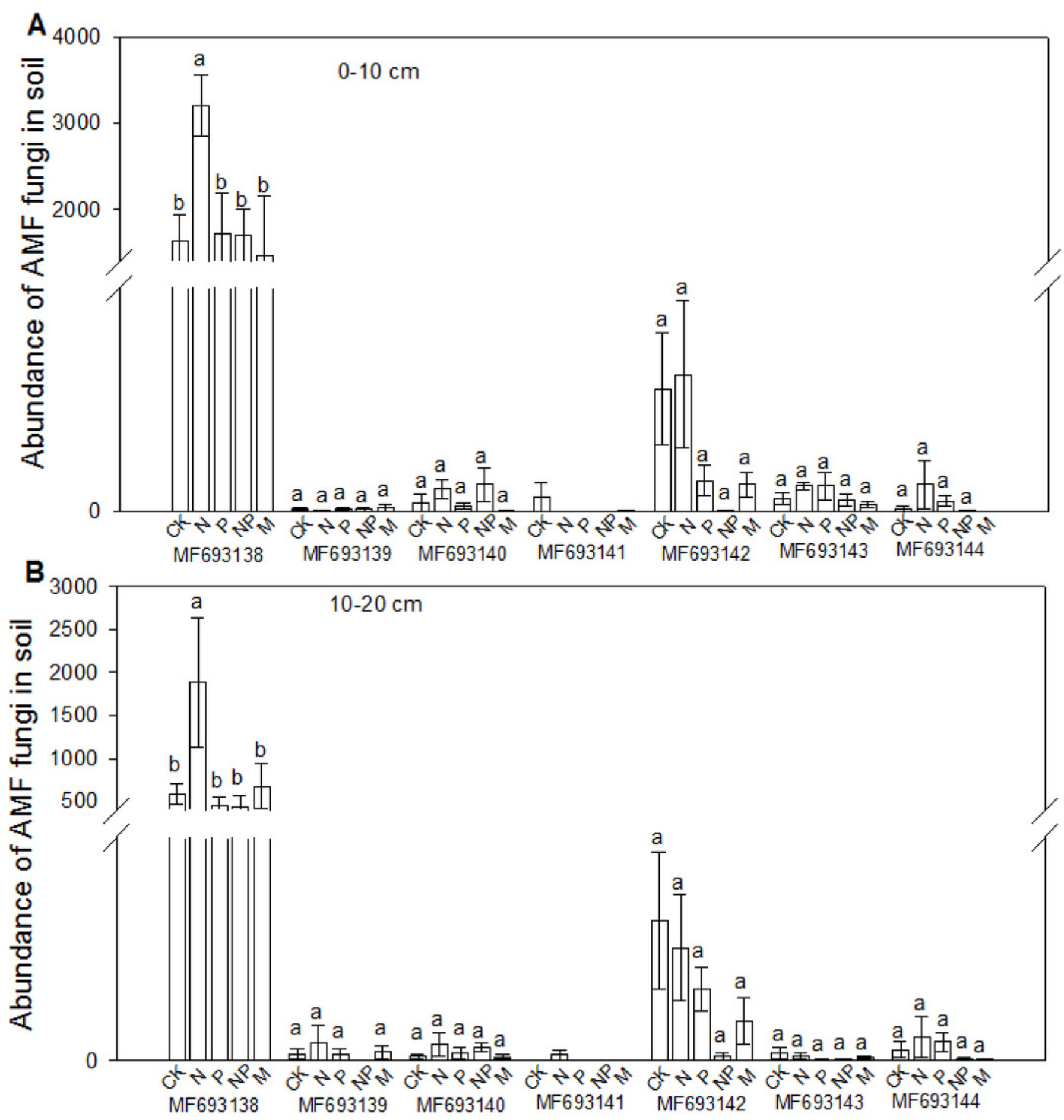


\section{Figure 6}

Spearman Correlation Heatmap between bacterial and soil properties at 0-10 $\mathrm{cm}$ (A) and $10-20 \mathrm{~cm}(B)$ and fungi and soil properties at $0-10 \mathrm{~cm}(C)$ and $10-20 \mathrm{~cm}(D)$.

AN, alkaline hydrolyzed N; AP, available P; AK, available potassium; MBC, microbial biomass $C ;$ MBN, microbial biomass $N$. The $R$ values are displayed in different colors and the right color card of the heat map is a color partition of different $\mathrm{R}$ values. $0.01<P<=0.05 * 0.001<$ $P<=0.01$ ** $P<=0.001$ ***. CK, Control; P, $60 \mathrm{~kg} \mathrm{P} \mathrm{ha}^{-1} ; \mathrm{N}, 100 \mathrm{~kg} \mathrm{~N} \mathrm{ha}^{-1} ; \mathrm{NP}, 60 \mathrm{~kg} \mathrm{P}^{2} a^{-1}$ plus $100 \mathrm{~kg} \mathrm{~N} \mathrm{ha}^{-1} ; \mathrm{M}, 4000 \mathrm{~kg}$ sheep manure ha-1. Lowercase letter "u" after treatment represented samples from 0-10 cm soil layer; "d" represented samples from $10-20 \mathrm{~cm}$ soil layer. 

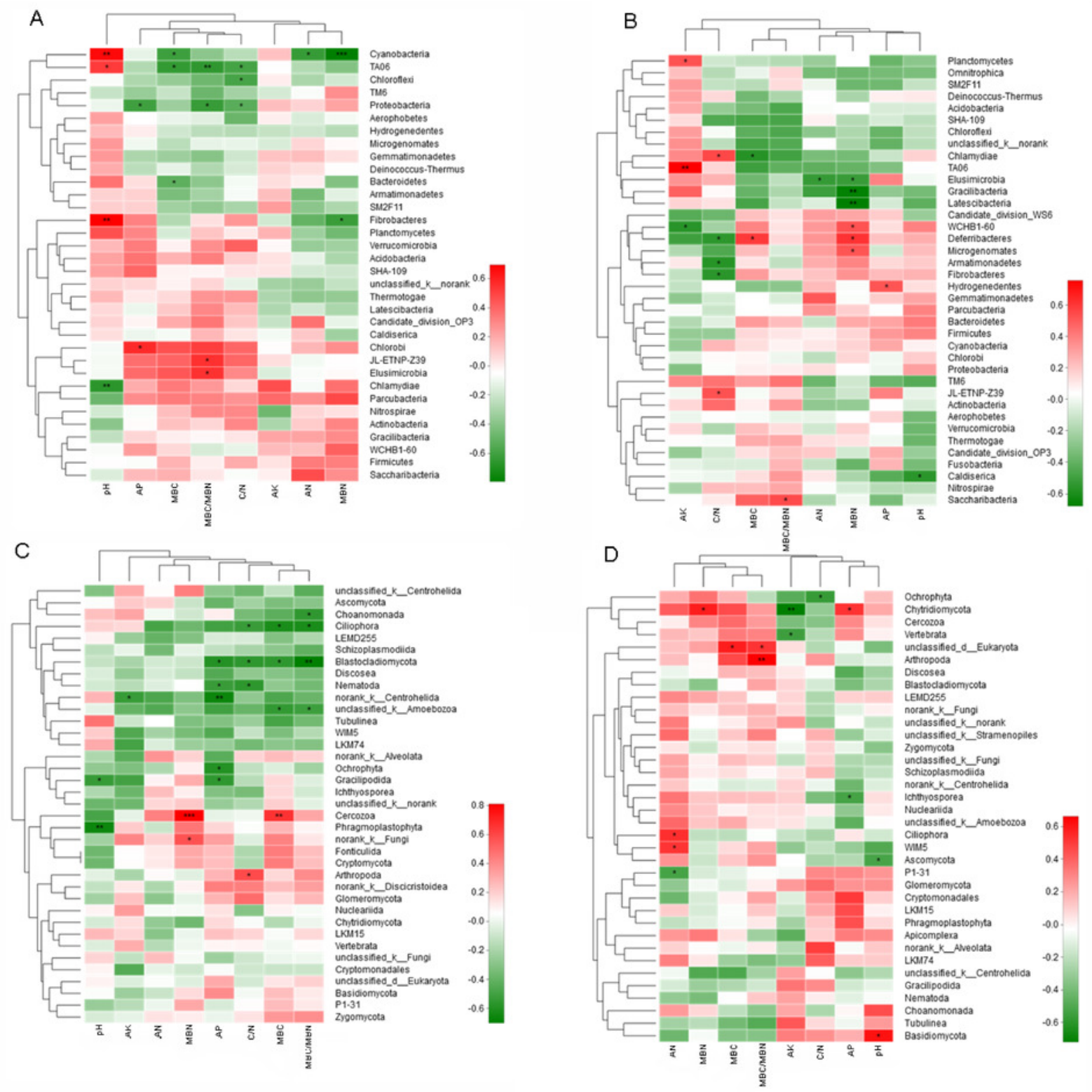